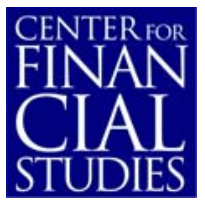

No. $2010 / 07$

Hold-Up in Multiple Banking: Evidence from SME Lending

Antje Brunner and Jan Pieter Krahnen 


\section{Center for Financial Studies}

The Center for Financial Studies is a nonprofit research organization, supported by an association of more than 120 banks, insurance companies, industrial corporations and public institutions. Established in 1968 and closely affiliated with the University of Frankfurt, it provides a strong link between the financial community and academia.

The CFS Working Paper Series presents the result of scientific research on selected topics in the field of money, banking and finance. The authors were either participants in the Center's Research Fellow Program or members of one of the Center's Research Projects.

If you would like to know more about the Center for Financial Studies, please let us know of your interest.

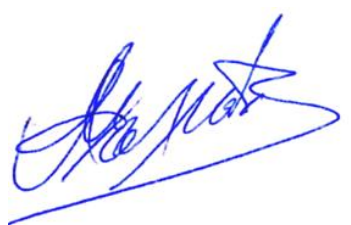

Prof. Michalis Haliassos, Ph.D.
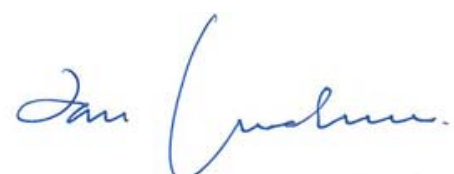

Prof. Dr. Jan Pieter Krahnen

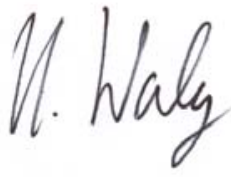

Prof. Dr. Uwe Walz 


\title{
Hold-Up in Multiple Banking: Evidence from SME Lending*
}

\author{
Antje Brunner ${ }^{1}$ and Jan Pieter Krahnen ${ }^{2}$
}

May 2010

\begin{abstract}
:
This paper analyzes loan pricing when there is multiple banking and borrower distress. Using a unique data set on SME lending collected from major German banks, we can instrument for effective coordination between lenders, carrying out a panel estimation. The analysis allows to distinguish between rents that accrue due to single bank lending, rents that accrue due to relationship lending, and rents that accrue due to the elimination of competition among multiple lenders. We find the relationship lending to have no discernible impact on loan spreads, while both single lending and coordinated multiple lending significantly increase the spread. Thus, contrary to predictions in the literature, multiple lending does not insure the borrower against hold-up.
\end{abstract}

JEL Classification: D74, G21, G33, G34

Keywords: Banking Competition, Coordination, Distress, Credit Spread, Hold-up

\footnotetext{
* This research is part of the CFS project on the Banking System Architecture in Germany. We thank all participating banks for the intensive cooperation in this project.

1 Humboldt University Berlin and Center for Financial Studies (CFS), Frankfurt, Germany 


\section{Introduction}

The benefits of relationship lending under asymmetric information have been studied widely, both theoretically and empirically (see Freixas (2005) and Boot (2000) for a survey). A growing body of literature has demonstrated that close and enduring relationships between a firm and its banker can at least partially bridge the informational asymmetry between the two parties. Such relationships can create value in several ways. First, established relationships may improve credit availability, particularly in difficult times. Second, it will increase the lender's willingness to renegotiate its loan terms and to support borrower workout. Third, relationships reduce the likelihood of inefficient liquidations of firms. These value enhancing features have been shown to survive even under the pressure of a systemic financial crisis (Puri, Rocholl and Steffen (2009)).

Much less attention, however, has been devoted to the potentially darker side of relationship lending, its role in limiting competition, barring market entry, and holding-up the borrower (Boot and Thakor (2000)). Of course, a prerequisite for a hold-up of a borrower by its lender is the elimination of actual or potential outside competition. Since it is difficult to observe outside competition at the level of individual firm financing, direct evidence on hold-up premiums in credit spreads is difficult to estimate, and we are not aware of any such attempt in the literature.

The key idea of this paper is to focus attention on the coordination between mul- 
tiple lenders vis-à-vis a common borrower. In order to capture coordination among lenders, we use data from the German SME market where binding contractual pool agreements between lenders are observed, notably if borrowers are in distress. Brunner and Krahnen (2008) describe the institutional details of commonly used pool arrangements. Based on the existence of such pool contracts, we can instrument for the coordination among multiple lenders, and thus trace the effect of limiting lender competition on the observed loan spread.

Our main findings can be summarized as follows. First, for single bank relationships we find a significant spread premium which is higher for well collateralized single banks compared to less collateralized ones. For relationship lenders (housebanks) we cannot observe such a premium, be it in or out of distress. Second, if multiple bank lenders successfully coordinate their positions using a pool arrangement, there is a significant increase in credit spreads relative to uncoordinated multiple banking. The spread premiums for coordinated lenders rise with the number of lenders and in distress. Alongside, a significantly positive dependency of the spread on borrower risk as well as loan rate smoothing with respect to interest rate shocks can be confirmed.

The main conclusion we draw from our findings is that contrary to the predictions in parts of the theoretical literature on financial intermediation, multiple lending is not necessarily a strong impediment against a hold-up by the lender. All it needs is a legal environment that exempts a binding agreement between lenders from anti-trust 
legislation as long as it relates to a common borrower in distress. Our results suggest that even if the number of lenders is large, contract renegotiation and opportunism play an important role in lending relationships.

The rest of the paper is organized as follows. Section 2 reviews the relevant theoretical and empirical literature. Based on this, Section 3 derives the hypotheses to be tested in this study. The data set and its descriptive statistics are described in Section 4. Section 5 presents the estimation methodology and estimation results. All results and their relevance for current research and policy are subsumed in the concluding section 6 .

\section{Literature}

\section{$2.1 \quad$ Theoretical background}

There is an extensive body of literature on interest rate setting in loan markets. In a principal-agent framework it is assumed that the agent's or loan applicant's quality or ability to repay a loan is private information and cannot be credibly communicated to the principal, i.e. the bank. The bank only observes the average quality of loan applicants. There are several reasons why the interest rate does not simply reflect the average default risk of loan applicants and why not every applicant is granted a loan.

First, Fried and Howitt (1980) find interest rate smoothing within optimal con- 
tracting between a lender and a risk-averse borrower in fear of interest rate shocks. In their risk-neutral model Stiglitz and Weiss (1981) find there will be credit rationing in loan market equilibrium because the interest rate itself affects the riskiness of the pool of loans in two ways, i.e. the ex ante or adverse selection effect where high interest attracts high risk borrowers, and the ex post incentive or moral hazard effect where high interest encourages the borrower to switch to riskier projects once the contract has been signed. Extending this line of thought, Bester (1985) suggests a menu of loans contracts combining interest rate and collateral as a self selection device where low-risk borrowers choose low interest and high collateral and high risk borrowers select the opposite, high interest and low collateral.

Diamond (1984) develops a model of financial intermediation, where monitoring is delegated to a financial intermediary avoiding either duplicated monitoring or no monitoring as a consequence of free-riding. In Diamond (1989) a non-defaulting borrower then creates reputation over the course of the lending relationship resulting in decreasing interest rates. Greenbaum, Kanatas and Venezia (1989) predict that incumbent banks charge loan rates that are higher than their cost of funds and higher than the loan rates offered by competing outside banks, i.e. outsiders incur initial losses in order to attract customers which have to be offset by positive rents in later periods. Therefore, the longer a relationship lasts the more likely is the borrowing firm to leave. 
Although relationship building reduces the moral hazard problem on the borrower side, the relationship itself may create moral hazard on the part of the lender called hold-up as discussed in Greenbaum, Kanatas, and Venezia (1989), Sharpe (1990) and Rajan (1992). Hold-up evolves according to Rajan (1992) when the reputation the borrower creates in a bank-borrower relationship regarding one's loan repayment is non-verifiable to outsiders. Thus, when borrowing from a single lender, this lender is given an informational advantage over potential competitors, and he is able to realize a rent at the refinancing stage. Given a competitive environment, banks will offer potential borrowers lower interest rates in the first period that are exceeded by their cost of funds, and recoup thereafter when having created an informational advantage vis-à-vis outside lenders. Gorton and Kahn (2000) present a model in which bank loans are always renegotiated in contrast with bonds, and initial loan pricing does not reflect borrower quality. It rather is utilized to optimize the bank's bargaining position in later renegotiation by minimizing moral hazard, namely asset substitution. Thus loan pricing may be non-linear in borrower risk including initial transfers to either side of the contract. Rajan (1992) as well as Bolton and Scharfstein (1996), and Berglof et al. (2000) conclude that multiple lending, i.e. borrowing from more than one lender helps mitigating the lender's moral hazard and deter the borrower from strategic default. However, it does not come without cost. Multiple debt is harder to renegotiate or non-renegotiable even when liquidation is inefficient. 
There is also an ever-growing literature discussing the lender's monitoring incentives. So far the literature treated a lender's monitoring effort as exogenous. In his model, Diamond (1989) explains how the delegation of monitoring to a financial intermediary prevents both duplication of monitoring as well as free-riding. Carletti (2004) develops a theoretical model of how a firm's monitoring incentives are affected by the number of bank relationships and how loan rates are affected by the bank's monitoring. She concludes that multiple banking does not necessarily increase loan rates. In Carletti, Cerasi and Daltung (2007) multiple lending is a means of risk mitigation through diversification. Its benefits have to be balanced against the cost of free-riding and excessive monitoring, caused by duplication.

\section{$2.2 \quad$ Empirical evidence}

Empirical evidence on the determinants of loan spreads goes back to the early nineteen nineties. We start this survey of the relevant literature with a study by Petersen and Rajan (1994) of the U.S. National Survey of Small Business Finance which was influential for many subsequent studies. The authors compare the reputation argument brought forward by Diamond (1989) and the hold-up theme as identified by Sharpe (1990) and Rajan (1992). Their results are in favor of reputation, i.e. borrowing from multiple banks implies higher interest. However, the relationship length has a positive impact on availability of credit, but little impact on its interest rate. Berger 
and Udell (1995) restrict their data to short-term lines of credit (L/C) financing small businesses and do not find evidence of hold-up neither. They show that small firms with mature relationships pay lower interest rates and provide less collateral when measuring relationship intensity by its duration. When differentiating between concentrated and competitive markets within the same data set, Petersen and Rajan (1995) find interest rate smoothing over the life cycle of the firm in concentrated markets, where young entrepreneurs are charged lower interest and surviving older ones are charged higher interest in order to recoup initial losses. With competition, creditors cannot expect to participate in entrepreneur's future surplus and will therefore charge the higher competitive interest rate initially and the lower competitive interest rate later on. Analyzing loan data from 126 U.S. banks between 1977-1989, Berlin and Mester (1998) do not find evidence of loan rate smoothing in response to credit risk shocks. However, there is evidence for smoothing with respect to interest rate risk, especially for larger banks, independent of the character of the relationship. This result corresponds with Berger and Udell (1992) who find loan rates to be sticky as compared to open-market rates over the same period.

In a study of German SME data, Harhoff and Körting (1998) find the short-term interest rate charged on lines of credit $(\mathrm{L} / \mathrm{C})$ to be dependent on firm size and firm age, financial distress, the number of bank relationships, and the firm's location. Small firms, young firms, firms with more bank relationships, firms in cities, and 
firms in financial distress pay higher interest, whereas the relationship duration does not affect pricing. A survey of housebanks in German SME lending by Elsas and Krahnen (1998) does not give evidence of compensatory pricing for housebanks, i.e. credit spreads are unaffected by the relationship status. Analyzing the same data set, Machauer and Weber (1998) prove housebanks to demand a higher amount of collateral rather than higher interest compared to non-housebanks. Furthermore, they find a positive relationship between loan rates and borrower risk as measured by the bank's internal risk classification.

For Italy, Foglia, Laviola and Marullo-Reedtz (1998) analyze the impact of multiple lending on the riskiness of corporates which they find is positive due to reduced monitoring efforts. They conclude that one main bank relationship helps restoring borrower discipline. In another study of Italy's bank lending business to large and medium-sized firms, D'Auria, Foglia, and Reedtz (1999) ascertain that the closeness of the relationship as measured by the bank's share in her client's total debt is the main component of the credit spread where a higher share results in a lower spread. Hold-up occurs only for almost exclusive relationships. The authors reason that concentrating loans with one main bank while establishing other bank relationships too is the best strategy to benefit from the main bank's informational advantage while preventing hold-up.

In an empirical paper, Brunner and Krahnen (2008) study the aspect of renego- 
tiation of distressed debt in a sample of German SMEs. They find an institution called 'bank pool' which acts as a coordination device and enhances multiple lenders' ability to renegotiate, even increasing the probability of successful turnaround of a distressed borrower when the number of banks involved is small. However, they did not look at the pricing of loans when this coordination device is in place and whether it renders hold-up possible in a multiple banking environment.

In this paper, we will analyze the determinants of the short-term loan spread of German SMEs with special emphasis on the bank pool. We will show whether the incidence of a bank pool has a significant impact on the spread.

\section{Hypotheses}

Based on the theoretical and empirical literature reviewed, we will summarize the main hypotheses to be tested in this study. First of all, without taking into account any sort of agency conflicts, the loan spread should reflect the probability distribution of repayments from the loan granted to a firm. The higher the default probability of a firm, the higher is the spread charged to compensate for losses in the event of default.

H1: $\quad$ The loan spread increases in borrower risk. Borrowers with higher default probabilities are charged higher prices for loans. (RISK)

The rating of a borrowing firm has been designed to measure default risk. How- 
ever, most of the parameters entering the calculation of a rating do themselves provide a restricted measure of risk, e.g. the industry a firm is operating in or her age. Since public rating agencies generally do only provide ratings for larger firms raising public debt, most SMEs do not obtain such a public rating. However, banks have established similar internal rating systems by which they can systematically judge the creditworthiness of their clients or potential clients, although these rating are not displayed to the public. Estimation in this study will rely on these internal ratings.

The spread is measured as the difference between the loan's contracted interest rate and the bank's reference interest rate. Fried an Howitt (1980) provide a theoretical model for interest rate smoothing within optimal contracting for risk-averse firms fearing interest rate shocks. The spread thus varies inversely with the level of the risk-free rate. An additional reason for the smoothing of the loan rate, relative to the market rate, draws on the relationship lending literature (Boot 2000 for a survey). The duration of the relationship has been shown to proxy well for relationship intensity. This would suggest that with longer duration the liquidity insurance implied by the smoothing of the contractual rate will increase, as the risk of opportunistic behavior by the firm is decreasing. This argument is consistent with Ongena and Smith (2001) who show that a relationship is not a one-way street, and firms do not necessarily get locked up in these relationships.

H2: $\quad$ Observed short-term loan spreads vary inversely with the corresponding 
risk-free market rate. (INTEREST RATE SMOOTHING)

Once the bank entered a relationship with the borrowing firm, it learns over time about firm's quality, i.e. her ability to service loans. Monitoring incentives are restored with a main or relationship bank and discipline the borrowing firm. Nondefaulting firms acquire reputation over time and will face a lower spread according to Diamond's (1989) reputation building argument. .

H3: $\quad$ The spread decreases with the length of the relationship. (REPUTATION)

When monitoring the client firm a bank should be able to realize economies of scope if the borrower is large in terms of its turnover. Alternatively, if size is measured by assets, the variable may indicate bargaining power, too. In both cases we expect:

H4: $\quad$ The spread is negatively related to the size of the borrowing firm. (SIZE) The reputation argument is often extended to other measures of uncertainty as for instance the age of a firm (see Petersen and Rajan (1995)).

A firm who has established a relationship with a single bank may however not be able to credibly convey her reputation to outsiders. The incumbent bank is able to extract a rent from the client in this so-called hold-up situation. Outside banks are not willing to undercut the incumbent as they fear a winner's curse problem. The winner's curse argument becomes even more severe if the single bank holds part or all of the collateral of the borrower. 
H5: $\quad$ The spread is non-decreasing or even increasing over the course of a single or main relationship, particularly if the relationship is collateralized. (HOLD-UP)

Competition in lending markets, via multiple lending, will contribute to a decrease in observed loan spreads, and it will prevent hold-up situations in repeated lending relationships. Therefore, by itself competition from transactional relationships may strengthen the outside funding options of the firm, reducing the scope for hold-up situations. On the other hand, competition among multiple lenders may be eliminated in times of borrower distress, as has been shown by Brunner and Krahnen (2008). They demonstrate that in German SME lending, banks tend to collude by forming pools at the start of a distress episode. The pool has been shown to facilitate borrower workout, ahead of any bankruptcy-related court intervention. While pool formation impedes a creditor run on borrower assets, it has not yet been tested whether the pool is also used to enforce excess compensation, e.g. in the form of increased loan rates. We hypothesize that, as a result of pool formation, competition is eliminated and the observed spread will rise above the market level. Furthermore, the excess spread during pool episodes will be larger if the level of competition (i.e. the number of bank relationships) prior to pool formation was relatively high. Finally, as an additional sign of hold-up, the competitive nature of the banking market may only gradually reappear after termination of the distress episode, i.e. after re-emergence of a borrower from distress. We therefore expect the pool-enforced excess spread to 
persist for some time after termination of the distress episode. This leads to

H6: $\quad$ Collusion of banks during borrower distress generates an excess spread in short-term lending rates. The excess spread is increasing in the number of bank relationships involved, and it persists even after termination of the distress period. (COLLUSION)

\section{Sampling, descriptive statistics and institutional design}

\subsection{The data set}

The study relies on the CFS Loan Data Set, collected under the Center for Financial Studies' field research project on Credit Management (see Elsas et al. (1998) for further details). The data underlying our analysis include corporate debtors of five major German banks; three of them are private listed firms, one is a public sector institution, and one is a cooperative bank. The unit of observation is a particular borrowing firm or, more specifically, a particular bank-borrower relationship, using all the information regarding the borrowing firm contained in the credit files of a bank. The data set contains in particular

- general characteristics of the firm (e.g. legal form, industry);

- the firm's balance sheet data;

- an assessment of borrower risk, according to the bank's internal risk rating; 
- a complete account of the bank's outstanding loans vis-à-vis the particular borrower, taken from its loan book; this includes information on loan terms, e.g. volume, maturity, collateral, spread;

- general information concerning other bank relationships of the firm, including the existence of a bank pool;

- measures taken by the bank in order to reorganize or liquidate the firm, or its assets.

This information was collected directly from the banks' credit files. Observations range from January 1992 to January 1997. The sample was drawn randomly from a population of all those corporate customers who fulfilled the following set of conditions at least once during this time span.

- First, firms had to be medium-sized, i.e. with an annual turnover between $25-250 \mathrm{~m}$ EUR. Owing to the absence of surveillance by rating agencies and the lack of rigorous disclosure requirements, we expected this firm size segment to be subject to a significant degree of asymmetric information between lenders and borrowers, thus constituting a prime population for the analysis of issues related to relationship lending, loan contract design, and renegotiation.

- Second, to ensure a minimum level of information with regard to the client's total bank debt and the number of bank relationships, a minimum total loan 
size of about $1.5 \mathrm{~m}$ EUR (3m DM) was imposed. All loans surpassing this level are subject to the regulatory notification requirement of Article 14 of the KWG (German Banking Act), and have to be communicated to the federal banking supervisory agency BAFin (formerly BAKred).

- Third, firms with registered offices in the former GDR (East Germany) were excluded.

All firms fulfilling these three conditions established population 'A'. The population of firms fulfilling also the subsequent fourth condition is called population 'P'.

- Fourth, firms had recorded a poor internal rating at least once within the 19921997 period. A poor rating is defined as a rating of 5 or 6 on a standardized rating scale applied to all banks in the sample ranging from 1 (highest grade) to 6 (lowest grade).

After identification of the relevant populations 'A' and 'P' respectively, two samples of 25 clients from 'A' and 15 clients from 'P' were drawn from each bank respectively. This yields a sample 'A' consisting of 125 clients and a sample 'P' of 75 clients. For each of these firms a set of some 200 variables were observed on a yearly basis. Due to missing observations for some of the relevant variables during the core time period from 1993-1996 studied in this paper, we reduced the samples to 103 firms 
in sample 'A' and 58 firms in sample 'P' with a total of 644 observations per year between 1993 and $1996 .^{2}$ Table 1 shows the composition of the two samples with respect to the banks providing the data.

\{insert Table 1 here\}

Variables include firm-level characteristics such as legal form, industry classification, and balance sheet information. Furthermore, we collected relationship characteristics as for instance duration, loan volume, loan type, pricing, collateralization, and rating. Besides quantitative information on the firm level and with respect to the banking relationship we also gathered information on how banks behave once the client enters distress including the formation of bank pools.

\subsection{Bank pools}

The institution of a 'bank pool' as observed in the data studied here is a formal contractual arrangement in which lenders pool their individual claims vis-à-vis a particular borrower in distress in order to coordinate their decision-making. Typically, when a firm with multiple bank relationships becomes distressed, its banks summon a so-called 'bank meeting'. This meeting serves the purpose of discussing how to deal with the firm currently in distress, and deciding in particular whether or not a formal

\footnotetext{
${ }^{2}$ When there was more than one observation per year we only considered the last observation. However, when there were distress measures undertaken by the bank during a year, we cumulated this information over all observations of the respective year.
} 
pool among the banks should be set up. In case this latter decision is affirmative, the contract is concluded without delay. The pool contract is signed by all active bank lenders and co-signed by the client borrower. It includes a sharing rule regarding revenues and costs from reorganization as well as an information sharing requirement which obliges all bank members to inform each other of circumstances that endanger loan repayment. If a pool bank breaches the contract, e.g. by unilaterally reducing her credit line, it becomes liable vis-à-vis the remaining pool banks to restore the agreed pool quotas. Both together is apparently sufficient to prevent preemptive action by contracting parties. For an extensive description of the bank pool see Brunner and Krahnen (2008).

Third parties are not necessarily informed about the establishment of a pool, if the firm's distress hasn't been disclosed yet. The liquidity situation of a troubled firm would be adversely affected by that signal.

The duration of the pool arrangement is unlimited, a priori. Once established, it will last until the reorganization is completed, i.e. until the firm is able to attract new lenders, or else until it is liquidated. In either case, the pool contract is phased out rather than formally dissolved. Empirically, the pool is not always resolved immediately after successful reorganization, i.e. we observe numerous cases where the pool is sustained for some time after rating has already been upgraded.

On the face of it, the pool contract seems to establish an oligopoly of banks 
coordinating their actions and therefore a reasonable case for any anti-trust law. So why could it be adopted for such a long time without intervention. Of course, German anti-trust law has reviewed the bank pool. It ruled that the installation of the bank pool aims at the reorganization of the client borrower rather than collusion of banks to the disadvantage of the borrower. Therefore it received temporary permission for the duration of reorganization. However, there has not been any empirical verification of this position which we will try to deliver in this paper.

In the following we will describe the data set with respect to borrower characteristics, the borrower's bank relationship observed in this sample, and, in more detail, the risk evaluation and loan pricing decision conducted by the bank.

\subsection{Borrower characteristics}

Looking at the industry affiliation of the firms sampled in A and P, about one third of all 161 firms belong to the manufacturing industry and further 24 per cent are active in machinery industry as shown in Table 2. Ostentatiously, the proportion of machinery firms in sample $\mathrm{P}$ is much larger than in sample A presumably related to the strong downturn of the machinery business in Germany in the first half of the 1990s.

\{insert Table 2 here $\}$ 
Also presented in Table 2, the predominant legal form is the limited liability firm with some $90 \%$ of the firms sampled in A, even increasing over the sampling period by changes of the legal form. However, in sample $\mathrm{P}$ the percentage of unlimited liability firms is almost twice as high in 1993 (20.7\%) compared to sample A (10.7\%), but decreasing until 1996 by one third.

While sampling conditions required the firms to be medium-sized with an annual turnover between 25 - 250m EUR, the average annual turnover ranges from $86.39 \mathrm{~m}$ EUR in 1993 to $98.55 \mathrm{~m}$ EUR in 1996 in sample A (see Table 3). Average annual turnover in sample $\mathrm{P}$ is somewhat smaller ranging from $78.65 \mathrm{~m}$ EUR in 1993 to 87.85m EUR in 1996. Measuring firm size in terms of total assets, sample A shows average total assets between 51.04 and $59.59 \mathrm{~m}$ EUR whereas sample P's total assets range from 56.71 to $65.01 \mathrm{~m}$ EUR, both increasing over the observation window. The opposing signs of the differences between sample A and sample P, i.e. P shows lower turnover combined with higher asset value than A, raises a first conjecture that sample $\mathrm{P}$ firms are in worse economic shape. This observation can be confirmed by looking at performance data. Where sample $\mathrm{A}$ firms show on average a rather continuous positive average annual return before taxes (ROI approximately 11-12\%), sample P's yearly average ROI fluctuates around zero between 1993 and 1996.

\{insert Table 3 here\} 
A look at debt numbers presented in Table 3 shows that the average debt ratio of sample A firms is less than $60 \%$ whereas sample P's average debt ratio reaches more than $70 \%$. Seen in the context of total debt financing, banks finance around $70 \%$ of total debt in the representative sample A and some three quarters of debt in sample $\mathrm{P}$. In line with this observation, firms in sample $\mathrm{P}$ pay on average some $50 \%$ more in annual interest than sample A firms. The percentage of bank loans among total debt is about 6 percentage points higher for sample $\mathrm{P}$ compared to $\mathrm{A}$.

Firms sampled in A or $\mathrm{P}$ have on average 6 bank relationships, although at the median firms in sample $\mathrm{P}$ have 1-2 more bank relationships than those sampled in $\mathrm{A}$.

\subsection{Relationship characteristics}

Looking at the particular five banks providing the data for this study, average total exposure of these bank relationships amounts to 8 to $8.5 \mathrm{~m}$ EUR in sample A (8.8 to 9.1m EUR in sample P; for all relationship descriptives see Table 4).

\section{\{insert Table 4 here\}}

The average bank relationship has lasted for 20.2 years by 1993 for sample A compared to 17.2 years for sample P. The banks from which the data were collected describe themselves to be a housebank in about $43 \%$ of relationships in sample A whereas only $31 \%$ of the collecting banks of sample P did so. Bank pools are involved with the borrowers in $11.6-14.6 \%$ of sample A relationships, but $27.6 \%$ up to $56.9 \%$ 
of sample P relationships by 1996.

From general relationship characteristics we turn to the loan facility level now. The fraction of short term credit lines (L/C) is $40-44 \%$ in sample A and slightly smaller in sample $\mathrm{P}$.

The loan spread measured as the difference between the nominal loan interest rate and the 3-months FIBOR (Frankfurt Interbank Offered Rate) increases between 1993 and 1996 and is systematically higher for sample P firms presumably related to higher default risk.

Higher default risk of sample P firms may also be the reason for higher collateralization. Information regarding the collateralization of exposure is displayed in Table 5. Collateralization of sample A relationships is on average about $29-33 \%$ of the exposure whereas it amounts to $41-46 \%$ for sample P. Restricting our view to only those relationships with a strictly positive collateral valuation, collateralization ranges from $42-46 \%$ in sample A to $49-51 \%$ in sample $\mathrm{P}$. The most important type of collateral is mortgage. More than $80 \%$ of collateral value for those sample A firms with strictly positive collateral valuation stem from mortgages compared to about $72-79 \%$ for sample P.

\{insert Table 5 here\} 


\subsection{Internal ratings}

The default risk of firms sampled in $\mathrm{A}$ or $\mathrm{P}$ is reflected in the bank-individual assessment of borrower's creditworthiness. Banks translate their risk evaluation into a risk rating ranked on a bank-individual rating scale following the assessment of a set of risk categories specified by each bank respectively. Internal ratings provided by bank lenders are a crucial characteristic of our data set as the above description of the sampling procedure demonstrated. The rating reflects the expected default probability of the firm, as seen by the bank, before collateralization is taken into account. We have no evidence of external ratings for any of the firms in our sample, i.e. agency ratings, which is reasonable given the fact that we are dealing with SMEs.

The rating information has been collected on every borrower and for each observation recorded in the files. Each bank in the sample uses its own rating system in order to assess the probability of default of its borrowers. Ratings are reviewed at regular intervals.

The standard methodology of the rating process relies on a scoring system including quantitative and qualitative information about firm performance and prospects, and a linear weighting system with both fixed and varying weighting factors depending on the bank in question (see Brunner et al. (2000) for details). We treat ratings as unbiased and efficient estimates of expected default probabilities, as judged by the individual bank. As long as internal ratings remain the private information of the 
bank, i.e. as long as rating information is not communicated to either the management of the rated firm, or to some supervisory body, there is no inherent incentive for the bank to systematically misrepresent the information available. Internal ratings are thus expected to be informationally efficient (see Krahnen and Weber (2001)).

In order to compare ratings from distinct banks one needed a superior rating scheme standardizing bank-individual ones. The standardization process is based on the verbal descriptions of bank-individual rating categories taken from the banks' rating manuals that instruct credit officers about how to assign a firm to a certain rating category. Using these descriptions, each category of a bank-individual rating system is assigned to one of the six new categories of the standardized system from 1 (lowest risk) to 6 (highest risk, default or imminent default) documented in Table 6 . Table 6 also relates the bank-individual rating categories and the standardized scale to the rating scales of Moody's and S\&P adapted from bank-internal translation rules.

$$
\text { \{insert Table } 6 \text { here\} }
$$

Based on this standardized rating scheme, Table 7 exhibits the rating distribution for samples A and P. It shows that sample A does not contain a single rating 6 over the period from 1993 to 1996. Unsurprisingly, ratings of sample $\mathrm{P}$ are inferior to sample A ratings by more than one category. This observation is unsurprisingly since a rating of 5 or 6 on this transformed rating scale, at least once between 1992 and 1996, is a prerequisite for being drawn to sample P. More interesting in this regard 
are yearly rating migrations exemplified in Table 7 through migrations from 1993 to 1994. It illustrates that the probability of rating migrations, up or down, is higher for sample P firms. Ratings of around $70 \%$ of sample A firms remain constant from one year to the subsequent year whereas only around $60 \%$ of the ratings of sample $\mathrm{P}$ do not change. Additionally, there is a tendency to migrate downwards rather than upwards in sample P not observed in sample A.

$$
\text { \{insert Table } 7 \text { here }\}
$$

\subsection{Estimation methodology and results}

Estimation in this study addresses the question what determines the bank's loan pricing, i.e. the spread above FIBOR (Frankfurt Interbank Offered Rate) charged on short-term lines of credit (L/C). Due to the lack of a high volume of cross-sectional data, we intend to use both the cross-sectional as well as the time series dimension of the available data set using a panel data model. The equation to be estimated is the following

$$
y_{i t}=\alpha+X_{i t}^{\prime} \beta+u_{i t} \quad i=1, \ldots, N ; \quad t=1, \ldots, T
$$

with $i$ denoting the firm and $t$ denoting the year of observation with $N=161$ and $T=4$. The error term is composed as follows

$$
u_{i t}=\mu_{i}+v_{i t}
$$


where $\mu_{i}$ denotes the individual effect of a firm which is unobservable and timeinvariant, and $v_{i t}$ is the remaining error varying with time and from firm to firm. Since firms observed in our data set are randomly drawn from the population of all firms borrowing from one of the five banks in this study and fulfilling certain requirements described in the previous chapter we can assume $\mu_{i}$ to be random and independent of $v_{i t}$.We will therefore estimate a one-way error random effects model with $y_{i t}$ being the dependent variable namely the spread on short-term lines of credit. Compared to the fixed effects model this technique avoids the loss of numerous degrees of freedom.

Furthermore we pool the representative sample A and the problem sample $\mathrm{P}$ in order to cover the full range of rating categories. Our presumption is that the bankinternal risk evaluation as the bank's measure of the firm's probability of default is most important in explaining the bank's pricing decision. Due to the limited size of the representative sample A with 103 firms observed over 4 years, we do almost exclusively observe rating categories 1 through 4 rather than 5 or 6 which gives us only an incomplete picture of the relationship between rating and loan pricing. We avoid this problem by pooling the representative sample $\mathrm{A}$ with sample $\mathrm{P}$ which covers a considerably higher percentage of lower rating categories. It is understood that the pooling is controlled for in the regression. A caption of variables used in the regressions is given in Table 8 . As mentioned above the dependent variable of the one-way error random effects panel regression is the spread above FIBOR charged on 
lines of credit by the respective bank.

\{insert Table 8 here\}

Before turning to the estimation results we briefly summarize the hypotheses to be tested. We hypothesized that the spread is positively related to the borrower risk as measured by the bank-internal rating $\{\mathbf{H 1}:(+)\}$. Since the spread itself is the difference between the loan's nominal interest and the bank's reference rate, changes in the reference rate may not be immediately translated into changes of the loan rate, leading to interest rate smoothing, i.e. an inverse relationship between the loan rate and the reference rate, FIBOR in this case $\{$ H2: $(-)\}$. The spread should however decrease over the duration of the relationship according to Diamond's (1989) reputation building argument $\{$ H3: (-) $\}$. Economies of scope associated with large size borrowers and their resulting bargaining power should coerce the bank to offer lower rates to larger clients $\{\mathbf{H} 4:(-)\}$. As a trade-off against the economies of scope effect attributed to single-sourcing, an exclusive bank relationship carries the risk of hold-up, caused by the lack of informed competition $\{$ H5: $(+)\}$. In general, if there are multiple lenders extending credit to a common borrower, collusion among the banks during borrower distress will support an increase of the spread. The observed excess spread under lender collusion will increase in the number of relationships, and it may last even after termination of the distress period. $\{\mathbf{H 6}:(+)\}$. 
The results reported in Table 9 show a strong effect of borrower risk on loan pricing. Firms with the lowest bank-internal risk assessment (rating categories 1 or 2) are used as a reference group. As Table 9 demonstrates, riskier borrowers (rating categories 3 to 6 ) face a significantly higher loan spread and the coefficients of rating dummies are increasing in risk, where higher rating notches correspond to higher default risk. The coefficients are highly significant in all specifications of the model. This is consistent with hypothesis H1.

\section{\{insert Table 9 here}

Addressing the loan spread as the difference between the contracted nominal interest rate on short-term lines of credit and the prevailing inter-bank market interest rate, the FIBOR, only the nominal rate is set by the bank. The regression coefficient of the market rate reveals whether loan rates are pro- or countercyclical. In the latter case loan rates are smoothing market movements. As can be seen from Table 9, the coefficient of the FIBOR3M is significantly negative, supporting hypothesis H2. Thus, there is evidence of interest rate smoothing in our data as banks at least partially insure their borrowers against short-run volatility of market interest rates.

Relationship duration has no significant impact on the spread, implying that either the length of a relationship is not a good proxy for borrower reputation, or there is no unidirectional learning effect in borrower-lender relationships. Hypothesis H3 is rejected. 
Hypothesis $\mathrm{H} 4$ addresses possible economies of scope and cross selling effects, as well as the effect of borrowers' bargaining power on the loan rate. The coefficient of the logarithm of borrower's annual turnover is negative and significant. Thus, the loan spread decreases in the size of the borrowing firm, supporting hypothesis H4. We employ a second size variable in all specifications, proxying for borrower assets. We find both coefficients to be significant at or above the $5 \%$ level where asset size, which may be interpreted as a proxy for bargaining power is more relevant in loan rate formation than cross selling arguments which may be related to business flow, or turnover. Testing for economies of scale on the bank's side we also introduced the bank's total exposure vis-à-vis the borrower measuring borrower size in terms of loans; the coefficient is not significant here.

We next turn to the impact of hold-up on the loan spread when there is a strong bank lender with an informational advantage, either a sole bank lender or a main lender (i.e. the housebank), as hypothesized in H5. The relevant variable for a sole bank lender, SINGLEBANK, is significant at $5 \%$ and $10 \%$ level for different specifications while the housebank variable is not. Note that the interaction term of the single bank and the uncollateralized portion of exposure is significantly negative. It signifies an increase in bargaining power, when the single bank also holds collateral rights. A possible explanation rests on the limited outside options of a borrower with a single bank and fewer assets left for pledging to outside lenders. Higher 
collateralization by itself is significantly related to higher spreads. This observation is consistent with descriptive statistics demonstrating higher collateralization for sample P compared to sample A. Concluding from both observations, banks demand more collateral from riskier borrowers while charging them higher spreads, too.

Hypotheses $\mathrm{H} 6$ is the main hypothesis in this paper, referring to the elimination of lender competition, and its impact on the loan spread.

The key variable, POOL, captures the structured cooperation among creditors thereby eliminating the competition that may have existed before pool formation. Such pools are tolerated by German courts to the extent that they are set up to organize a borrower workout or resolution. In Table 9 , the coefficient of the POOL variable is positive and highly significant, supporting hypothesis H6. The presence of lender coordination significantly raises the spread, after controlling for other sources of spread heterogeneity like default risk, firm size, bank identity and so forth. This result is found to be robust in a number of alternative specifications.

In regression (vi) of Table 9, we distinguish between small and large pools. Defining a SMALL POOL-dummy comprising the lower tertile of the number of banks (up to 4 bank relationships), and a dummy for LARGE POOL with five or more banks. Results show that the pool effect clearly depends on the number of banks involved. For small pools the coefficient is small, in absolute terms, and only weakly significant at the $10 \%$ level. Large pools capture the main effect on the spread. Its coefficient is 
larger, in absolute terms, and it is highly significant. Thus, the change in competition intensity, which is higher with more lenders, generates a higher excess spread.

In model (vii) the effect of the pool on spreads is analyzed separately for two distinct episodes in the life of the borrowing firm, namely distress and non-distress periods. The internal rating serves to distinguish between these periods. Interestingly, and consistent with the idea that collusion leads to a 'hang-over' in that the excess spread continues to exist even when the reason for the collusion, the borrower distress has been resolved. We find the pool to be highly significant even after an upgrade of the internal rating. This clearly shows that the pool is also an anti-competitive instrument which, once in place, has a life of its own. However, pools do not exist forever, so we find the post-distress excess spread to be lower relative to in-distress periods, suggesting a slow decay of lender collusion.

Finally, the bank identity also plays a role as emanated from significant bank effects in our regression.

The pooling of samples $\mathrm{A}$ and $\mathrm{P}$ is indirectly controlled for by the inclusion of the rating dummy for rating classes 5-6 as sample $\mathrm{P}$ requires such a rating to be observed at least once during the observation window. To test robustness we also replicated regression (v) of Table 9 as the base case including a sampling dummy equal to 1 if the observation is from sample $\mathrm{P}$ and zero if it is from sample A. Results are shown in specification (v.P) with no substantial differences to the previous regression results. 
The key variable in our estimations is the POOL variable. We cannot exclude the possibility that there is endogeneity in our setup. The economic argument for endogeneity is that pools may be formed precisely because the relevant determinants for a potential hold-up situation are anticipated by the lenders, and they therefore are able to agree on a pool contract more easily. In this case, the same variables that determine an excess spread will also determine whether or not a pool is formed. To control the implied bias in the estimation, we run a two stage estimation. The estimated values from a first stage pool formation regression are used to replace the pool dummy in the second stage regression. Table 10 reports the results. We find all results discussed already confirmed.

$$
\text { \{insert Table } 10 \text { here\} }
$$

\section{Conclusion}

Multiple lending in bank-borrower relationships plays an important role in the theory of banking and corporate finance. In this paper we add new insights to the role of multiple banking, only partly supporting the claims made in the theoretical literature. Relying on a panel data set of 161 bank-firm relationships taken from the files of 5 German banks traced over a 4-years period (1993-1996), we identify determinants in loan rate setting for short-term SME loans.

We find the credit spread to be sensitive with respect to the bank's risk assess- 
ment of the borrower's default risk with positive sign and high significance. We also find loan rate smoothing with respect to interest rate shocks. A significant hold-up premium has been identified for exclusive bank relationships, but not for relationship lenders with superior information such as housebanks. When assessing the banking relationship by its duration, we find no significant impact on the spread .

The major result of our analysis relates to the role of multiple banking in loan rate setting. The majority of firms in the sample have more than one bank relationship, averaging 6 over the entire sample, with a maximum value of 19 . We find strong evidence for lender coordination by means of a bank pool in situations of borrower distress, leading to a significantly higher loan spread. The increase is also high in economic terms, averaging about 35 basis points. A priori it is unclear whether this large increase in loan spread reflects an increased effort extended by the pool banks in order to work out the distressed borrower, or a hold-up premium charged by coordinated banks, or a combination of both. Our results strengthen the presumption that the potential hold-up through multiple coordinated banks is effectively exercised. However, the hold-up premium carries over to post-distress periods, where we observe a decay of the premium as new competition from outside banks presumably kicks in again.

Our results show that, in contrast to some predictions in the literature, the fact that lenders are numerous does not necessarily imply they are unable or unwilling to 
coordinate their interest. Once coordination of multiple lenders becomes a realistic scenario, hold-up is no longer limited to single lenders.

\section{References}

BALTAGI, B. H. (2008), Econometric Analysis of Panel Data (Chichester: John Wiley \& Sons Ltd).

BERGER, A. N. and UDELL, G. F. (1995), "Relationship Lending and Lines of Credit in Small Firm Finance", Journal of Business, 68, 351-381.

BERGLOF, E., ROLAND, G. and VON THADDEN, E.-L. (2000), ”An Incomplete Contracts Approach to Corporate Bankruptcy" (mimeo).

BERLIN, M. and L. J. MESTER (1998), "On the Profitability and Cost of Relationship Lending", Journal of Banking 8 Finance, 22, 873-897.

BESTER, H. (1985), "Screening vs. Rationing in Credit Markets with Imperfect Information", The American Economic Review, 75, 850-855.

BOLTON, P. and SCHARFSTEIN, D. S. (1996), "Optimal Debt Structure and the Number of Creditors", The Journal of Political Economy, 104, 1-25.

BOOT, A. W. A. (2000), "Relationship Banking: What Do We Know?", The Journal of Financial Intermediation, 9, 7-25. 
BOOT, A. W. A. and THAKOR, A. V. (2000), "Can Relationship Banking Survive Competition?", The Journal of Finance, 55, 679-713.

BRIS, A. and WELCH, I. (2005), "The Optimal Concentration of Creditors", The Journal of Finance, 60, 2193-2212.

BRUNNER, A. and KRAHNEN, J. P. (2008), "Multiple Lenders and Corporate Distress: Evidence on Debt Restructuring", The Review of Economic Studies, 75, 415-442.

BRUNNER, A., KRAHNEN, J. P. and WEBER, M. (2000), "Information Production in Credit Relationships: On the Role of Internal Ratings in Commercial Banking" (Center for Financial Studies Working Paper No. 2000/10).

CARLETTI, E. (2004), "The Structure of Relationship Lending, Endogenous Monitoring and Loan Rates", The Journal of Financial Intermediation, 13, $58-86$.

CARLETTI, E., CERASI, V. and DALTUNG, S. (2007), "Multiple-bank Lending: Diversification and Free-riding in Monitoring", The Journal of Financial Intermediation, 16, 425-451.

D'AURIA, C., FOGLIA, A. and MARULLO REEDTZ, P. (1999), "Bank In- 
terest Rates and Credit Relationships in Italy", Journal of Banking $\mathscr{6}$ Finance, 23, 1067-1093.

DETRAGIACHE, E., GARELLA, P. and GUISO, L. (2000), "Multiple versus Single Banking Relationships: Theory and Evidence", The Journal of Finance, 55, 1133-1161.

DIAMOND, D. W. (1984), "Financial Intermediation and Delegated Monitoring", The Review of Economic Studies, 51, 393-414.

DIAMOND, D. W. (1989), "Reputation Acquisition in Debt Markets", The Journal of Political Economy, 97, 828-862.

ELSAS, R., HENKE, S., MACHAUER, A., ROTT, R. and SCHENK, G. (1998), "Empirical Analysis of Credit Relationships in Small Firm Financing: Sampling Design and Descriptive Statistics" (Center for Financial Studies Working Paper No. 1998/14).

ELSAS, R. and KRAHNEN, J. P. (1998), "Is Relationship Lending Special? Evidence from Credit-File Data in Germany", Journal of Banking and Finance, 22, 1283-1316.

ELSAS, R. and KRAHNEN, J. P. (1999), "Collateral, Default Risk, and Rela- 
tionship Lending: An Empirical Study on Financial Contracting" (Center for Financial Studies Working Paper No. 1999/13).

FOGLIA, A. LAVIOLA, S. and P. MARULLO REEDTZ (1998), "Multiple Banking Relationships and the Fragility of Corporate Borrowers", Journal of Banking \& Finance, 22, 1441-1456.

FREIXAS, X. (2005), "Deconstructing Relationship Banking", Investigaciones Económicas, 29, 3-31.

FRIED, J. and HOWITT, P. (1980), "Credit Rationing and Implicit Contract Theory", Journal of Money, Credit and Banking, 12, 471-487.

GORTON, G. and KAHN, J. (2000), "The Design of Bank Loan Contracts", The Review of Financial Studies, 13, 331-364.

GREENBAUM, S. I., KANATAS, G. and VENEZIA, I. (1989), "Equilibrium Loan Pricing Under the Bank-Client Relationship", Journal of Banking \& Finance, 13, 221-235.

HARHOFF, D. and KÖRTING, T. (1998), "Lending Relationships in Germany - Empirical Evidence from Survey Data", Journal of Banking 8 Finance, 22, $1317-1353$. 
KRAHNEN, J. P. and WEBER, M. (2001), "Generally Accepted Rating Principles: A Primer", Journal of Banking and Finance, 25, 2-24.

MACHAUER, A. and WEBER, M. (1998), "Bank Behavior Based on Internal Credit Ratings of Borrowers", Journal of Banking E Finance, 22, 1355-1383.

ONGENA, S. and SMITH, D. C. (2000), "What Determines the Number of Bank Relationships? Cross-Country Evidence", The Journal of Financial Intermediation, $\mathbf{9}, 26-56$.

ONGENA, S. and SMITH, D. C. (2001), "The duration of bank relationships", Journal of Financial Economics, 61, 449-475.

PETERSEN, M. A. and RAJAN, R. G. (1994), "The Benefits of Lending Relationships: Evidence from Small Business Data", The Journal of Finance, 49, $3-37$.

PETERSEN, M. A. and RAJAN, R. G. (1995), "The Effect of Credit Market Competition on Lending Relationships", The Quarterly Journal of Economics, 110, 407-443.

PURI, M., ROCHOLL, J. and STEFFEN, S. (2009), "The Impact of the U.S. Financial Crisis on Global Retail Lending" (mimeo). 
RAJAN, R. (1992), "Insiders and Outsiders: The Choice between Informed and Arm's-Length Debt", The Journal of Finance, 47, 1367-1400.

RAJAN, R. and WINTON, A. (1995), "Covenants and Collateral as Incentives to Monitor", The Journal of Finance, 50, 1113-1146.

SHARPE, S. A. (1990), "Asymmetric Information, Bank Lending, and Implicit Contracts: A Stylized Model of Customer Relationships", The Journal of Finance, 45, 1069-1987.

STIGLITZ, J. E. and A. WEISS (1981), "Credit Rationing in Markets with Imperfect Information", The American Economic Review, 71, 393-410.

Appendix 
Table 1

Sampling

\begin{tabular}{lcc} 
Bank source & sample A & sample P \\
\hline Bank 1 & 20 & 12 \\
Bank 2 & 24 & 9 \\
Bank 3 & 21 & 13 \\
Bank 4 & 23 & 14 \\
Bank 5 & 15 & 10 \\
\hline Total & 103 & 58 \\
\hline
\end{tabular}

Table 2

Borrower - Frequency statistics

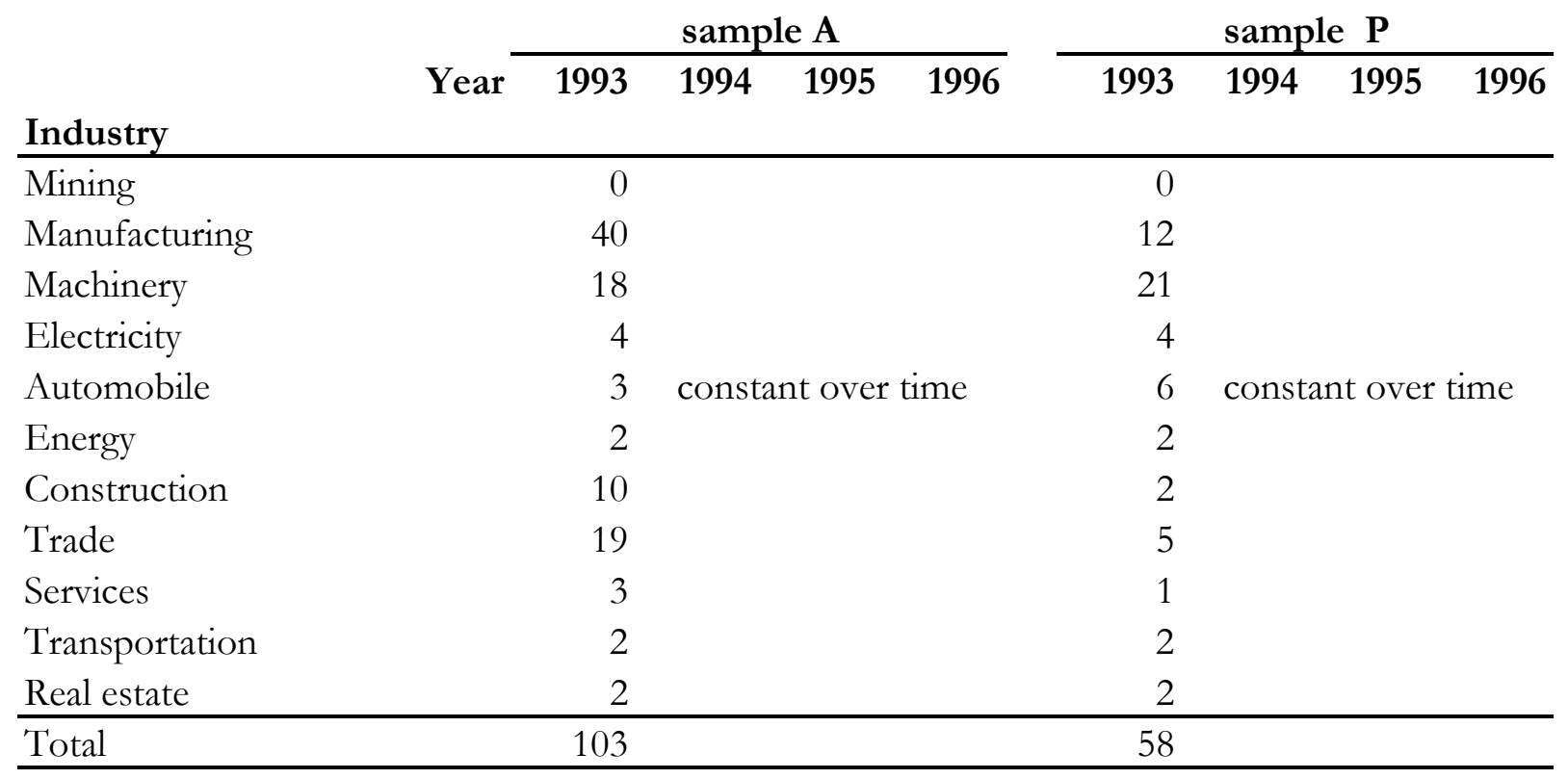

Legal form and liability

\begin{tabular}{llrrrrrrrr}
\hline Corporation & (limited) & 92 & 92 & 92 & 93 & 46 & 48 & 49 & 50 \\
Partnership & (unlimited) & 5 & 5 & 5 & 4 & 7 & 6 & 5 & 4 \\
Sole Proprietorship (unlimited) & 6 & 6 & 6 & 6 & 5 & 4 & 4 & 4 \\
\hline \multicolumn{1}{l}{ Total } & 103 & 103 & 103 & 103 & 58 & 58 & 58 & 58 \\
\hline
\end{tabular}

* There were 9 changes in legal form during the observation window 1993-1996 of which 5 changes were accompanied by a limitation of liability. 
Table 3

Borrower - Descriptive statistics

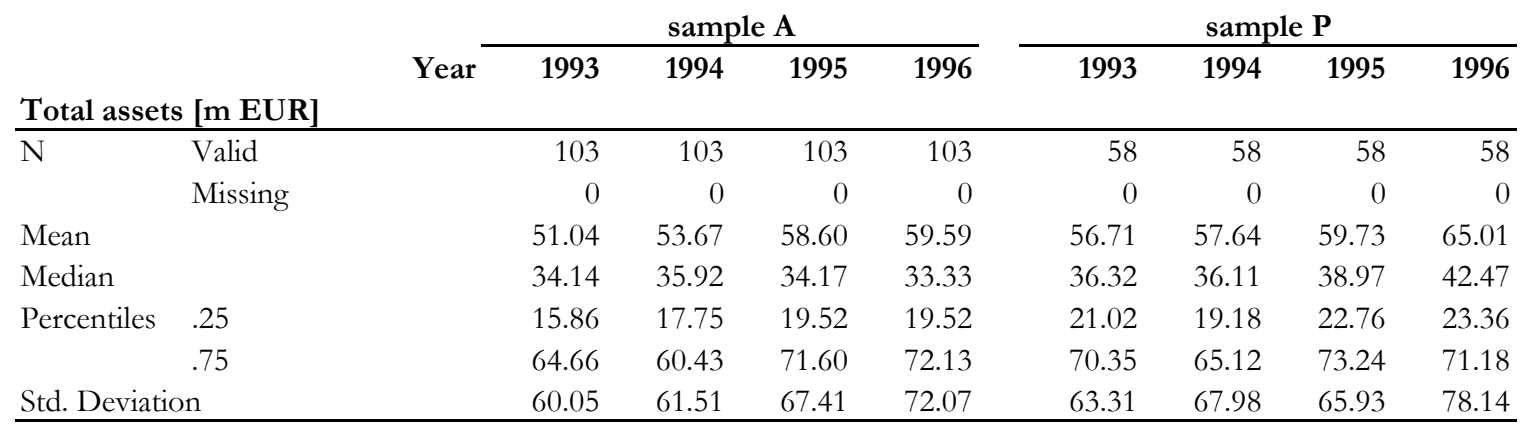

Annual turnover [m EUR]

\begin{tabular}{|c|c|c|c|c|c|c|c|c|c|}
\hline \multirow[t]{2}{*}{$\mathrm{N}$} & Valid & 103 & 103 & 103 & 103 & 58 & 58 & 58 & 58 \\
\hline & Missing & 0 & 0 & 0 & 0 & 0 & 0 & 0 & 0 \\
\hline \multicolumn{2}{|l|}{ Mean } & 86.39 & 92.10 & 96.12 & 98.55 & 78.65 & 74.31 & 76.04 & 87.85 \\
\hline \multicolumn{2}{|l|}{ Median } & 56.83 & 59.52 & 61.31 & 63.72 & 57.50 & 54.13 & 55.02 & 55.35 \\
\hline \multirow[t]{2}{*}{ Percentiles } & .25 & 31.43 & 33.64 & 37.35 & 34.95 & 30.03 & 24.72 & 29.33 & 32.12 \\
\hline & .75 & 103.04 & 106.78 & 115.93 & 120.17 & 104.00 & 90.85 & 109.14 & 104.22 \\
\hline \multicolumn{2}{|c|}{ Std. Deviation } & 115.07 & 111.19 & 113.71 & 118.75 & 74.95 & 71.64 & 68.34 & 100.70 \\
\hline \multicolumn{10}{|c|}{ Return on investment [\%] } \\
\hline \multirow[t]{2}{*}{$\mathrm{N}$} & Valid & 103 & 103 & 103 & 103 & 58 & 58 & 58 & 58 \\
\hline & Missing & 0 & 0 & 0 & 0 & 0 & 0 & 0 & 0 \\
\hline \multicolumn{2}{|l|}{ Mean } & $11 \%$ & $12 \%$ & $13 \%$ & $11 \%$ & $1 \%$ & $-2 \%$ & $0 \%$ & $-1 \%$ \\
\hline \multicolumn{2}{|l|}{ Median } & $5 \%$ & $5 \%$ & $6 \%$ & $4 \%$ & $1 \%$ & $-1 \%$ & $1 \%$ & $1 \%$ \\
\hline \multirow[t]{2}{*}{ Percentiles } & .25 & $2 \%$ & $2 \%$ & $1 \%$ & $1 \%$ & $-2 \%$ & $-6 \%$ & $-3 \%$ & $-2 \%$ \\
\hline & .75 & $13 \%$ & $16 \%$ & $14 \%$ & $13 \%$ & $3 \%$ & $2 \%$ & $3 \%$ & $3 \%$ \\
\hline \multicolumn{2}{|c|}{ Std. Deviation } & $19 \%$ & $20 \%$ & $31 \%$ & $31 \%$ & $5 \%$ & $11 \%$ & $8 \%$ & $11 \%$ \\
\hline
\end{tabular}

* annual profit before taxes / total assets

Indebtedness [\%]

\begin{tabular}{lcrrrrrrrr}
\hline $\mathrm{N}$ & Valid & 103 & 103 & 103 & 103 & 58 & 58 & 58 & 58 \\
& Missing & 0 & 0 & 0 & 0 & 0 & 0 & 0 & 0 \\
Mean & & $59 \%$ & $58 \%$ & $58 \%$ & $59 \%$ & $71 \%$ & $73 \%$ & $72 \%$ & $73 \%$ \\
Median & & $57 \%$ & $56 \%$ & $58 \%$ & $59 \%$ & $71 \%$ & $74 \%$ & $77 \%$ & $77 \%$ \\
Percentiles & .25 & $45 \%$ & $45 \%$ & $42 \%$ & $41 \%$ & $60 \%$ & $61 \%$ & $60 \%$ & $62 \%$ \\
& .75 & $72 \%$ & $72 \%$ & $74 \%$ & $74 \%$ & $83 \%$ & $86 \%$ & $87 \%$ & $88 \%$ \\
\multicolumn{2}{l}{ Std. Deviation } & $19 \%$ & $19 \%$ & $20 \%$ & $20 \%$ & $18 \%$ & $19 \%$ & $20 \%$ & $19 \%$ \\
\hline
\end{tabular}

* total debt / total assets

Bank debt share [\%]

\begin{tabular}{lcrrrrrrrr}
\hline $\mathrm{N}$ & Valid & 101 & 101 & 101 & 101 & 55 & 55 & 55 & 55 \\
& Missing & 2 & 2 & 2 & 2 & 3 & 3 & 3 & 3 \\
Mean & & $70 \%$ & $69 \%$ & $69 \%$ & $73 \%$ & $77 \%$ & $76 \%$ & $78 \%$ & $76 \%$ \\
Median & & $72 \%$ & $72 \%$ & $74 \%$ & $83 \%$ & $82 \%$ & $79 \%$ & $85 \%$ & $83 \%$ \\
Percentiles & .25 & $51 \%$ & $52 \%$ & $48 \%$ & $49 \%$ & $65 \%$ & $60 \%$ & $61 \%$ & $66 \%$ \\
& .75 & $100 \%$ & $99 \%$ & $100 \%$ & $100 \%$ & $93 \%$ & $97 \%$ & $100 \%$ & $98 \%$ \\
\multicolumn{2}{l}{ Std. Deviation } & $27 \%$ & $27 \%$ & $28 \%$ & $29 \%$ & $21 \%$ & $22 \%$ & $23 \%$ & $24 \%$ \\
\hline
\end{tabular}

* total bank debt / total debt

No. of bank relationships

\begin{tabular}{llrrrrrrrr}
\hline $\mathrm{N}$ & Valid & 103 & 103 & 103 & 103 & 58 & 58 & 58 & 58 \\
& Missing & 0 & 0 & 0 & 0 & 0 & 0 & 0 & 0 \\
Mean & & 5.85 & 5.85 & 5.85 & 5.92 & 6.52 & 6.05 & 6.07 & 5.93 \\
Median & & 4.00 & 4.00 & 4.00 & 5.00 & 6.00 & 6.00 & 6.00 & 6.00 \\
Percentiles & .25 & 3.00 & 3.00 & 3.00 & 3.00 & 4.00 & 4.00 & 4.00 & 4.00 \\
& .75 & 8.00 & 8.00 & 8.00 & 8.00 & 8.00 & 7.25 & 7.00 & 7.00 \\
\multicolumn{2}{l}{ Std. Deviation } & 4.89 & 4.82 & 4.89 & 4.89 & 3.71 & 3.12 & 3.07 & 3.00 \\
\hline
\end{tabular}


Table 4

Relationship - Descriptive statistics

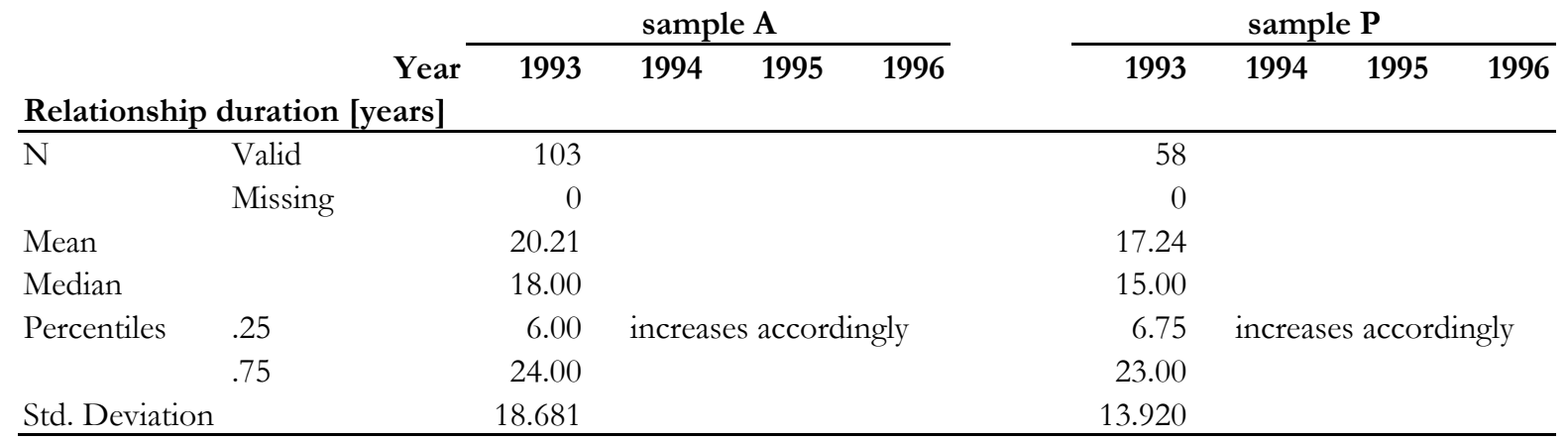

Housebank (dummy variable)

\begin{tabular}{|c|c|c|c|c|c|c|c|c|}
\hline yes & 43 & 45 & 44 & 44 & 18 & 17 & 18 & 19 \\
\hline no & 60 & 58 & 59 & 59 & 40 & 41 & 40 & 39 \\
\hline Total & 103 & 103 & 103 & 103 & 58 & 58 & 58 & 58 \\
\hline
\end{tabular}

Bank Pool (dummy variable)

\begin{tabular}{|c|c|c|c|c|c|c|c|c|}
\hline yes & 12 & 12 & 14 & 15 & 16 & 23 & 28 & 33 \\
\hline no & 91 & 91 & 89 & 88 & 42 & 35 & 30 & 25 \\
\hline Total & 103 & 103 & 103 & 103 & 58 & 58 & 58 & 58 \\
\hline
\end{tabular}

Total exposure [Million EUR]

\begin{tabular}{llrrrrrrrr}
\hline $\mathrm{N}$ & Valid & 103 & 103 & 103 & 103 & 58 & 58 & 58 & 58 \\
& Missing & 0 & 0 & 0 & 0 & 0 & 0 & 0 & 0 \\
Mean & & 8.04 & 8.32 & 8.06 & 8.47 & 9.10 & 8.90 & 9.12 & 8.81 \\
Median & & 5.07 & 5.11 & 4.60 & 5.30 & 6.84 & 5.62 & 5.57 & 5.28 \\
Percentiles & .25 & 2.77 & 2.84 & 2.65 & 2.81 & 3.58 & 3.55 & 3.39 & 2.99 \\
& .75 & 9.96 & 11.62 & 11.76 & 11.56 & 11.14 & 12.55 & 11.84 & 11.37 \\
\multicolumn{2}{l}{ Std. Deviation } & 8.31 & 8.49 & 8.57 & 8.73 & 8.20 & 8.18 & 8.96 & 8.66 \\
\hline
\end{tabular}

Short-term exposure [\%]

\begin{tabular}{lcrrrrrrrr}
\hline $\mathrm{N}$ & Valid & 100 & 100 & 99 & 96 & 53 & 52 & 51 & 50 \\
& Missing & 3 & 3 & 4 & 7 & 5 & 6 & 7 & 8 \\
Mean & & $44 \%$ & $43 \%$ & $44 \%$ & $40 \%$ & $39 \%$ & $40 \%$ & $43 \%$ & $40 \%$ \\
Median & & $39 \%$ & $35 \%$ & $38 \%$ & $34 \%$ & $33 \%$ & $35 \%$ & $31 \%$ & $36 \%$ \\
Percentiles & .25 & $20 \%$ & $20 \%$ & $19 \%$ & $18 \%$ & $19 \%$ & $20 \%$ & $19 \%$ & $19 \%$ \\
& .75 & $59 \%$ & $66 \%$ & $66 \%$ & $56 \%$ & $56 \%$ & $55 \%$ & $58 \%$ & $57 \%$ \\
\multicolumn{2}{l}{ Std. Deviation } & $28 \%$ & $29 \%$ & $30 \%$ & $29 \%$ & $26 \%$ & $25 \%$ & $45 \%$ & $29 \%$ \\
\hline
\end{tabular}

$*$ short-term lines of credit (LC) / total exposure

Short-term (LC) spread [\%]

\begin{tabular}{|c|c|c|c|c|c|c|c|c|c|}
\hline \multirow[t]{2}{*}{$\mathrm{N}$} & Valid & 103 & 103 & 103 & 103 & 58 & 58 & 58 & 58 \\
\hline & Missing & 0 & 0 & 0 & 0 & 0 & 0 & 0 & 0 \\
\hline \multicolumn{2}{|l|}{ Mean } & 3.15 & 3.54 & 3.64 & 3.80 & 3.53 & 4.01 & 4.31 & 4.70 \\
\hline \multicolumn{2}{|l|}{ Median } & 3.10 & 3.55 & 3.55 & 3.67 & 3.56 & 4.14 & 4.25 & 4.76 \\
\hline \multirow[t]{2}{*}{ Percentiles } & .25 & 2.64 & 2.88 & 2.96 & 3.11 & 3.04 & 3.18 & 3.39 & 3.86 \\
\hline & .75 & 3.69 & 4.01 & 4.15 & 4.41 & 4.28 & 4.81 & 4.99 & 5.38 \\
\hline \multicolumn{2}{|c|}{ Std. Deviation } & 0.815 & 0.778 & 0.858 & 0.925 & 1.245 & 1.316 & 1.350 & 1.506 \\
\hline
\end{tabular}

* nominal LC interest rate ./. FIBOR 
Table 5

Collateralization - Descriptive statistics

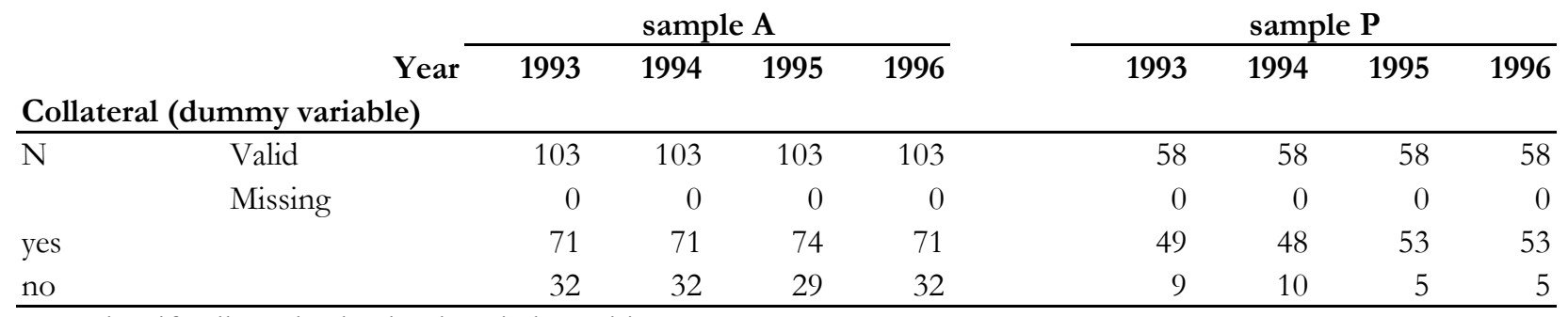

* equals 1 if collateral valuation is strictly positive

Collateralization [\%]

\begin{tabular}{|c|c|c|c|c|c|c|c|c|c|}
\hline \multirow[t]{2}{*}{$\mathrm{N}$} & Valid & 103 & 103 & 103 & 103 & 58 & 58 & 58 & 58 \\
\hline & Missing & 0 & 0 & 0 & 0 & 0 & 0 & 0 & 0 \\
\hline \multicolumn{2}{|l|}{ Mean } & $30 \%$ & $29 \%$ & $33 \%$ & $32 \%$ & $41 \%$ & $43 \%$ & $46 \%$ & $44 \%$ \\
\hline \multicolumn{2}{|l|}{ Median } & $24 \%$ & $27 \%$ & $27 \%$ & $27 \%$ & $39 \%$ & $37 \%$ & $41 \%$ & $40 \%$ \\
\hline \multirow[t]{2}{*}{ Percentiles } & .25 & $0 \%$ & $0 \%$ & $0 \%$ & $0 \%$ & $16 \%$ & $15 \%$ & $19 \%$ & $20 \%$ \\
\hline & .75 & $52 \%$ & $47 \%$ & $53 \%$ & $49 \%$ & $65 \%$ & $73 \%$ & $74 \%$ & $65 \%$ \\
\hline \multicolumn{2}{|c|}{ Std. Deviation } & $31 \%$ & $29 \%$ & $31 \%$ & $32 \%$ & $32 \%$ & $34 \%$ & $33 \%$ & $32 \%$ \\
\hline
\end{tabular}

* Collateral value / total exposure

Collateralization given collateral [\%]

\begin{tabular}{|c|c|c|c|c|c|c|c|c|c|}
\hline \multirow[t]{2}{*}{$\mathrm{N}$} & Valid & 71 & 71 & 74 & 71 & 49 & 48 & 53 & 53 \\
\hline & Missing & 0 & 0 & 0 & 0 & 0 & 0 & 0 & 0 \\
\hline \multicolumn{2}{|l|}{ Mean } & $43 \%$ & $42 \%$ & $45 \%$ & $46 \%$ & $49 \%$ & $51 \%$ & $50 \%$ & $49 \%$ \\
\hline \multicolumn{2}{|l|}{ Median } & $36 \%$ & $35 \%$ & $41 \%$ & $43 \%$ & $46 \%$ & $48 \%$ & $42 \%$ & $45 \%$ \\
\hline \multirow[t]{2}{*}{ Percentiles } & .25 & $21 \%$ & $25 \%$ & $23 \%$ & $25 \%$ & $29 \%$ & $23 \%$ & $24 \%$ & $25 \%$ \\
\hline & .75 & $62 \%$ & $59 \%$ & $60 \%$ & $59 \%$ & $69 \%$ & $78 \%$ & $78 \%$ & $69 \%$ \\
\hline \multicolumn{2}{|c|}{ Std. Deviation } & $28 \%$ & $26 \%$ & $28 \%$ & $29 \%$ & $28 \%$ & $31 \%$ & $32 \%$ & $30 \%$ \\
\hline
\end{tabular}

* Collateral value / total exposure | collateral value $>0$

Mortgage collateral [\%]

\begin{tabular}{llrrrrrrrr}
\hline $\mathrm{N}$ & Valid & 71 & 71 & 74 & 71 & 49 & 48 & 53 & 53 \\
& Missing & 0 & 0 & 0 & 0 & 0 & 0 & 0 & 0 \\
Mean & & $82 \%$ & $82 \%$ & $83 \%$ & $85 \%$ & $72 \%$ & $74 \%$ & $79 \%$ & $76 \%$ \\
Median & & $100 \%$ & $100 \%$ & $100 \%$ & $100 \%$ & $77 \%$ & $89 \%$ & $95 \%$ & $89 \%$ \\
Percentiles & .25 & $73 \%$ & $73 \%$ & $76 \%$ & $90 \%$ & $50 \%$ & $53 \%$ & $60 \%$ & $56 \%$ \\
& .75 & $100 \%$ & $100 \%$ & $100 \%$ & $100 \%$ & $100 \%$ & $100 \%$ & $100 \%$ & $100 \%$ \\
\multicolumn{1}{l}{ Std. Deviation } & $34 \%$ & $33 \%$ & $31 \%$ & $30 \%$ & $31 \%$ & $32 \%$ & $30 \%$ & $31 \%$ \\
\hline
\end{tabular}

* Mortgage value / collateral value | collateral value $>0$ 
Standardization

\begin{tabular}{|c|}
\hline $\begin{array}{l}\text { Standardized bank } \\
\text { rating }\end{array}$ \\
\hline $\begin{array}{c}1 \\
\text { outstanding quality }\end{array}$ \\
\hline $\begin{array}{c}2 \\
\text { good quality, } \\
\text { above average }\end{array}$ \\
\hline $\begin{array}{c}3 \\
\text { average quality, } \\
\text { increased risk }\end{array}$ \\
\hline $\begin{array}{c}4 \\
\text { speculative grade, } \\
\text { below average } \\
\text { quality }\end{array}$ \\
\hline $\begin{array}{c}5 \\
\text { problematic, } \\
\text { intensive care, } \\
\text { reorg. }\end{array}$ \\
\hline $\begin{array}{c}6 \\
\text { default, } \\
\text { reorg./ } \\
\text { liquidation }\end{array}$ \\
\hline
\end{tabular}

Bank-Internal Rating Categories

\begin{tabular}{|c|c|c|c|c|}
\hline Bank 1 & Bank 2 & Bank 3 & Bank 4 & Bank 5 \\
\hline $\begin{array}{c}1 \\
\text { very good risk }\end{array}$ & \begin{tabular}{|c|}
1 \\
outstanding quality
\end{tabular} & $\begin{array}{c}1.0-1.2 \\
\text { outstanding } \\
\text { quality, low risk }\end{array}$ & $\begin{array}{c}1 \\
\text { outstanding } \\
\text { performance, } \\
\text { lowest risk }\end{array}$ & $\begin{array}{c}1.00-1.49 \\
\text { outstanding quality }\end{array}$ \\
\hline $\begin{array}{c}2 \\
\text { good risk }\end{array}$ & $\begin{array}{c}2 \\
\text { good quality }\end{array}$ & $\begin{array}{c}1.3-2.7 \\
\text { good quality, } \\
\text { above average }\end{array}$ & $\begin{array}{c}2 \\
\text { high quality, } \\
\text { above average }\end{array}$ & $\begin{array}{c}1.50-2.49 \\
\text { good quality }\end{array}$ \\
\hline $\begin{array}{c}3-3 / 4 \\
\text { satisfactory/ } \\
\text { adequate risk }\end{array}$ & $\begin{array}{c}3 \\
\text { satisfactory quality } \\
\text { with weaknesses }\end{array}$ & $\begin{array}{c}2.8-3.7 \\
\text { average } \\
\text { quality/risk }\end{array}$ & $\begin{array}{c}3 \\
\text { average } \\
\text { performance }\end{array}$ & $\begin{array}{c}2.50-2.99 \\
\text { satisfactory quality }\end{array}$ \\
\hline $\begin{array}{c}4 \\
\text { sufficient risk }\end{array}$ & $\begin{array}{c}4 \\
\text { sufficient quality, } \\
\text { intensive care }\end{array}$ & $\begin{array}{c}3.8-4.2 \\
\text { speculative grade, } \\
\text { intensive care }\end{array}$ & $\begin{array}{c}4-5 \\
\text { sufficient quality, } \\
\text { increased risk }\end{array}$ & $\begin{array}{c}3.00-3.49 \\
\text { sufficient quality }\end{array}$ \\
\hline $\begin{array}{l}\text { 4/5-5 } \\
\text { just sufficient / } \\
\text { insufficient risk }\end{array}$ & $\begin{array}{c}5 \\
\text { deficient quality, } \\
\text { substantial } \\
\text { problems }\end{array}$ & $\begin{array}{c}4.3-5.7 \\
\text { default imminent, } \\
\text { intensive } \\
\text { care/reorg. }\end{array}$ & $\begin{array}{c}6-7 \\
\text { intensive care, } \\
\text { weak/neg. } \\
\text { prospects }\end{array}$ & $\begin{array}{l}3.50-4.49 \\
\text { low quality }\end{array}$ \\
\hline $\begin{array}{c}6 \\
\text { extremely bad risk }\end{array}$ & $\begin{array}{c}6-7 \\
\begin{array}{c}\text { inadequate quality, } \\
\text { default }\end{array}\end{array}$ & $\begin{array}{c}5.8-6.5 \\
\text { default, reorg./ } \\
\text { liquidation }\end{array}$ & $\begin{array}{c}8 \\
\text { default, operating } \\
\text { loss, neg. } \\
\text { prospects }\end{array}$ & $\begin{array}{c}4.50-5.00 \\
\text { default or } \\
\text { imminent default }\end{array}$ \\
\hline
\end{tabular}

Agencies' Rating Categories

\begin{tabular}{|c|c|c|}
\hline$S \& P$ & Moody & \\
\hline $\begin{array}{l}\text { AAA } \\
\text { AA+ } \\
\text { AA } \\
\text { AA- }\end{array}$ & $\begin{array}{l}\mathrm{Aaa} \\
\mathrm{Aa} 1 \\
\mathrm{Aa} 2 \\
\mathrm{Aa} 3\end{array}$ & $\begin{array}{l}\text { Highest to High } \\
\text { Investment } \\
\text { Grade }\end{array}$ \\
\hline $\begin{array}{c}\text { A1 } \\
\text { A2 } \\
\text { A3 } \\
\text { Baa1 } \\
\text { Baa2 }\end{array}$ & $\begin{array}{c}\mathrm{A}+ \\
\mathrm{A} \\
\mathrm{A}- \\
\mathrm{BBB}+ \\
\mathrm{BBB}\end{array}$ & $\begin{array}{c}\text { Upper Medium } \\
\text { to Medium } \\
\text { Investment } \\
\text { Grade }\end{array}$ \\
\hline $\begin{array}{l}\mathrm{Ba} 1 \\
\mathrm{Ba} 2 \\
\mathrm{Ba} 3\end{array}$ & $\begin{array}{c}\mathrm{BB}+ \\
\mathrm{BB} \\
\mathrm{BB}-\end{array}$ & $\begin{array}{c}\text { Speculative } \\
\text { Grade }\end{array}$ \\
\hline $\begin{array}{l}\text { B1 } \\
\text { B2 } \\
\text { B3 }\end{array}$ & $\begin{array}{c}\mathrm{B}+ \\
\mathrm{B} \\
\mathrm{B}-\end{array}$ & \\
\hline $\begin{array}{c}\text { Caa1 } \\
\text { Caa2 } \\
\text { Caa3 } \\
\text { Ca } \\
\text { C }\end{array}$ & $\begin{array}{c}\text { CCC+ } \\
\text { CCC } \\
\text { CCC- } \\
\text { CC } \\
\text { C }\end{array}$ & $\begin{array}{c}\text { Highly } \\
\text { Speculative } \\
\text { Grade }\end{array}$ \\
\hline $\mathrm{D}$ & $\mathrm{D}$ & Default \\
\hline
\end{tabular}


Table 7

Internal ratings - Frequency statistics

Rating distribution

\begin{tabular}{|c|c|c|c|c|c|c|c|c|}
\hline \multirow[b]{2}{*}{$\begin{array}{r}\text { Year } \\
\text { Borrower rating }(\%)\end{array}$} & \multicolumn{4}{|c|}{ sample $A(N=103)$} & \multicolumn{4}{|c|}{ sample $P(N=58)$} \\
\hline & 1993 & 1994 & 1995 & 1996 & 1993 & 1994 & 1995 & 1996 \\
\hline \multirow[t]{2}{*}{1} & 11 & 11 & 7 & 6 & 3 & 3 & 1 & 1 \\
\hline & $11 \%$ & $11 \%$ & $7 \%$ & $6 \%$ & $5 \%$ & $5 \%$ & $2 \%$ & $2 \%$ \\
\hline \multirow[t]{2}{*}{2} & 19 & 25 & 27 & 23 & 2 & 2 & 1 & 1 \\
\hline & $18 \%$ & $24 \%$ & $26 \%$ & $22 \%$ & $3 \%$ & $3 \%$ & $2 \%$ & $2 \%$ \\
\hline \multirow[t]{2}{*}{3} & 40 & 31 & 37 & 39 & 10 & 7 & 7 & 3 \\
\hline & $39 \%$ & $30 \%$ & $36 \%$ & $38 \%$ & $17 \%$ & $12 \%$ & $12 \%$ & $5 \%$ \\
\hline \multirow[t]{2}{*}{4} & 30 & 33 & 28 & 31 & 17 & 14 & 16 & 15 \\
\hline & $29 \%$ & $32 \%$ & $27 \%$ & $30 \%$ & $29 \%$ & $24 \%$ & $28 \%$ & $26 \%$ \\
\hline \multirow[t]{2}{*}{5} & 3 & 3 & 4 & 4 & 20 & 23 & 23 & 26 \\
\hline & $3 \%$ & $3 \%$ & $4 \%$ & $4 \%$ & $34 \%$ & $40 \%$ & $40 \%$ & $45 \%$ \\
\hline \multirow[t]{2}{*}{6} & 0 & 0 & 0 & 0 & 6 & 9 & 10 & 12 \\
\hline & $0 \%$ & $0 \%$ & $0 \%$ & $0 \%$ & $10 \%$ & $16 \%$ & $17 \%$ & $21 \%$ \\
\hline \multirow[t]{2}{*}{ Total } & 103 & 103 & 103 & 103 & 58 & 58 & 58 & 58 \\
\hline & $100 \%$ & $100 \%$ & $100 \%$ & $100 \%$ & $100 \%$ & $100 \%$ & $100 \%$ & $100 \%$ \\
\hline
\end{tabular}

Rating migration

TO (1994)

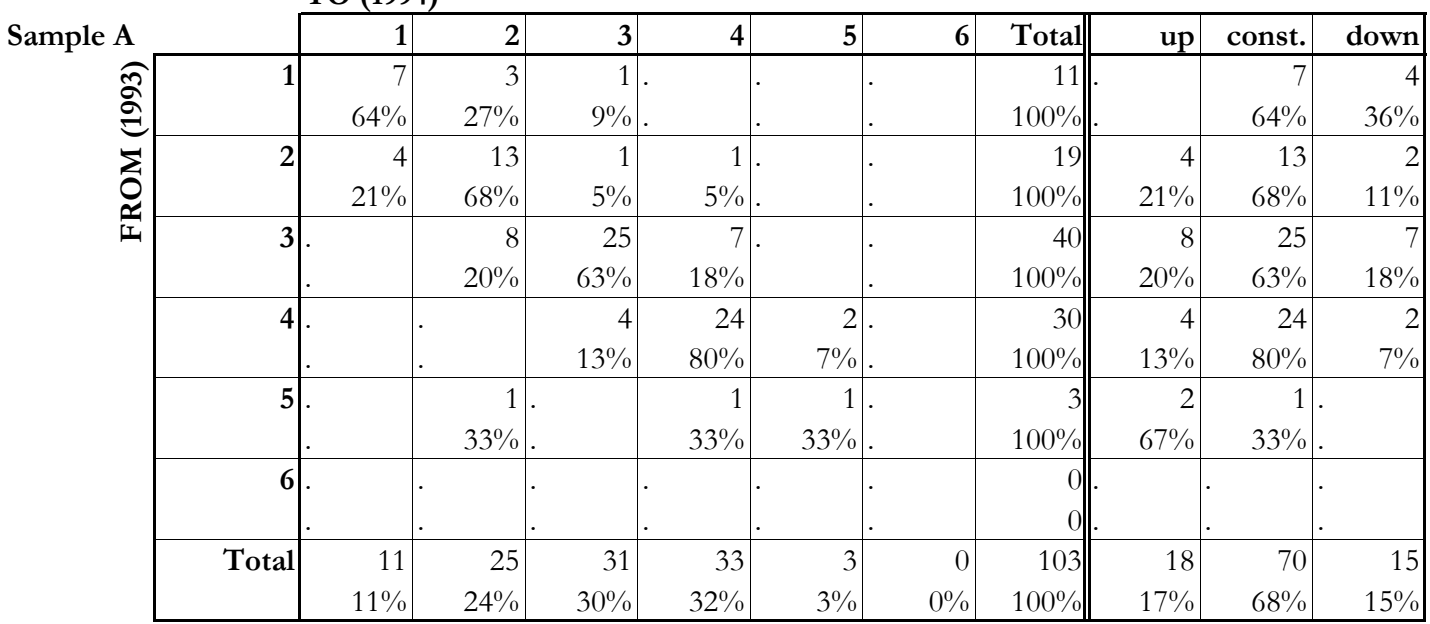

TO (1994)

\begin{tabular}{|c|c|c|c|c|c|c|c|c|c|c|c|}
\hline Sample P & & 1 & 2 & 3 & 4 & 5 & 6 & Total & up & const. & down \\
\hline & 1 & $\begin{array}{r}3 \\
100 \%\end{array}$ & & & & & & \begin{tabular}{r|}
3 \\
$100 \%$
\end{tabular} & & $\begin{array}{r}3 \\
100 \%\end{array}$ & \\
\hline$\sum_{0}$ & 2 & & $\begin{array}{r}2 \\
100 \% \\
\end{array}$ & & & & & $\begin{array}{r}2 \\
100 \% \\
\end{array}$ & & $\begin{array}{r}2 \\
100 \% \\
\end{array}$ & \\
\hline$\sqrt{I}$ & 3 & & & $\begin{array}{r}4 \\
40 \%\end{array}$ & $\begin{array}{r}4 \\
40 \%\end{array}$ & $\begin{array}{r}2 \\
0.2\end{array}$ & & $\begin{array}{r}10 \\
100 \%\end{array}$ & & $\begin{array}{r}4 \\
40 \%\end{array}$ & $\begin{array}{r}6 \\
60 \%\end{array}$ \\
\hline & 4 & & & $\begin{array}{r}2 \\
12 \%\end{array}$ & $\begin{array}{r}8 \\
47 \%\end{array}$ & $\begin{array}{r}6 \\
35 \%\end{array}$ & $\begin{array}{r}1 \\
6 \%\end{array}$ & $\begin{array}{r}17 \\
100 \%\end{array}$ & $\begin{array}{r}2 \\
12 \%\end{array}$ & $\begin{array}{r}8 \\
47 \%\end{array}$ & $\begin{array}{r}7 \\
41 \%\end{array}$ \\
\hline & 5 & & & $\begin{array}{r}1 \\
0.05\end{array}$ & $\begin{array}{r}2 \\
10 \%\end{array}$ & $\begin{array}{r}13 \\
65 \%\end{array}$ & 0.2 & \begin{tabular}{r||}
20 \\
$100 \%$
\end{tabular} & $\begin{array}{r}3 \\
15 \%\end{array}$ & $\begin{array}{r}13 \\
65 \%\end{array}$ & 4 \\
\hline & 6 & & & & & $\begin{array}{r}2 \\
33 \%\end{array}$ & $\begin{array}{r}4 \\
67 \%\end{array}$ & 6 & 2 & $\begin{array}{r}4 \\
67 \%\end{array}$ & \\
\hline & Total & $\begin{array}{r}3 \\
3 \%\end{array}$ & $\begin{array}{r}2 \\
2 \%\end{array}$ & $\begin{array}{r}7 \\
7 \%\end{array}$ & $\begin{array}{r}14 \\
14 \%\end{array}$ & $\begin{array}{r}23 \\
22 \%\end{array}$ & 9 & \begin{tabular}{r|}
58 \\
$56 \%$
\end{tabular} & $\begin{array}{r}7 \\
12 \%\end{array}$ & $\begin{array}{r}34 \\
59 \%\end{array}$ & $\begin{array}{r}17 \\
29 \%\end{array}$ \\
\hline
\end{tabular}


Table 8

Main Variable Definition

Variable Name

SPREAD

RATING1-2

RATING3

RATING4

RATING5-6

FIBOR3M

POOL

SMALLPOOL

LARGEPOOL

POOL WITHOUT DISTRESS

POOL IN DISTRESS

NUMBEROFBANKS

HOUSEBANK

SINGLEBANK

UNCOLLATERALIZED

HOUSEBANK $x$ UNCOLL.

SINGLEBANK $x$ UNCOLL. LOG(DURATION)

LIABILITY

LOG(SIZE)

LOG(SIZEA)

EXPOSURE

BANKDEBT

RETURNONIVESTMENT

BANK2

BANK3

BANK4

BANK5

SAMPLE P

IFO

YEAR1994

YEAR1995

YEAR1996
Type

numerical

Dummy $(0,1)$

Dummy $(0,1)$

Dummy $(0,1)$

Dummy $(0,1)$

numerical

Dummy $(0,1)$

Interaction dummy $(0,1)$

Interaction dummy $(0,1)$

Interaction dummy $(0,1)$

Interaction dummy $(0,1)$

numerical

Dummy $(0,1)$

Dummy $(0,1)$

numerical

numerical

numerical

in years

Dummy $(0,1)$

numerical

numerical

numerical

numerical

numerical

Dummy $(0,1)$

Dummy $(0,1)$

Dummy $(0,1)$

Dummy $(0,1)$

Dummy $(0,1)$

numerical

Dummy $(0,1)$

Dummy $(0,1)$

Dummy $(0,1)$

\section{Definition}

short-term nominal interest rate ./. FIBOR3M

equals 1 if internal rating category is 1 or 2 , zero otherwise

equals 1 if internal rating category is 3 , zero otherwise

equals 1 if internal rating category is 4 , zero otherwise

equals 1 if internal rating category is 5 or 6 , zero otherwise

3-month Frankfurt Interbank Offered Rate

equals 1 if there is a bank pool, zero otherwise

equals 1 if no. of bank relationships is at most 4 and a bank pool exists equals 1 if no. of bank relationships is 5 or higher and a bank pool exists equals 1 if rating class is 4 or lower (better) and bank pool exists equals 1 if rating class is 5 or 6 (distress) and bank pool exists number of firm's established bank relationships

equals 1 if observed bank is housebank, zero otherwise equals 1 if observed bank is sole bank lender, zero otherwise 1 - (collateral value / bank's total exposure)

equals uncollateralized portion of housebank's exposure, zero for others equals uncollateralized portion of single bank's exposure, zero for others natural $\log$ of length of the bank relationship in years

equals 1 if firm's legal form implies unlimited liability, zero otherwise natural $\log$ of firm's annual turnover from latest balance sheet natural $\log$ of firm's total assets from latest balance sheet bank's total exposure

total bank debt

earnings before taxes / total assets

equals 1 if firm is observed at bank 2, zero otherwise equals 1 if firm is observed at bank 3 , zero otherwise equals 1 if firm is observed at bank 4 , zero otherwise equals 1 if firm is observed at bank 5, zero otherwise equals 1 if observation is originated in sample $\mathrm{P}$ IFO business climate index

equals 1 if firm is observed in year 1994, zero otherwise equals 1 if firm is observed in year 1995, zero otherwise equals 1 if firm is observed in year 1996, zero otherwise 


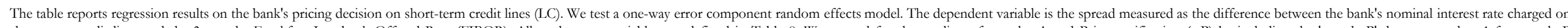
short-term credit lines and the 3-months Frankfurt Interbank Offered Rate (FIBOR). All explanatory variables are defined in Table 8. We control for the pooling of samples A and P in specification (v.P) by including the 'sample $\mathrm{P}^{\prime}$ dummy equal to 1 for sample $\mathrm{P}$ zero group variance cannot be rejected the pooled OLS regression is appropriate. If the LM-Test statistics is sufficiently large, the null hypothesis is rejected in favor of the random effects model.

\begin{tabular}{|c|c|c|c|c|c|c|c|c|c|c|c|c|c|c|c|c|}
\hline & (i) & & (ii) & & (iii) & & (iv) & & (v) & & (vi) & & (vii) & & (v.P) & \\
\hline & Coeff. & Std.Err. & Coeff. & Std.Err. & Coeff. & Std.Err. & Coeff. & Std.Err. & Coeff. & Std.Err. & Coeff. & Std.Err. & Coeff. & Std.Err. & Coeff. & Std.Err. \\
\hline RATING3 & 0.2394 & $0.1049 * *$ & 0.2458 & $0.1050 * *$ & 0.2490 & 0.1087 ** & 0.2225 & $0.1073 * *$ & 0.2446 & $0.1056 * *$ & 0.2495 & $0.1061 * *$ & 0.2474 & $0.1052 * *$ & 0.2158 & $0.1049 * *$ \\
\hline RATING4 & 0.3599 & $0.1126 * * *$ & 0.3763 & $0.1127 * * *$ & 0.3288 & $0.1174 * * *$ & 0.3447 & $0.1170 * * *$ & 0.3792 & $0.1131 * * *$ & 0.3881 & $0.1135 * * *$ & 0.3881 & $0.1133 * * *$ & 0.3173 & $0.1136 * * *$ \\
\hline RATING5-6 & 0.3904 & $0.1232 * * *$ & 0.4036 & $0.1225 * * *$ & 0.3768 & $0.1277 * * *$ & 0.3645 & $0.1295 * * *$ & 0.4100 & $0.1230 * * *$ & 0.4160 & $0.1233 * * *$ & 0.3499 & $0.1334 * * *$ & 0.2746 & $0.1287 * *$ \\
\hline FIBOR3M & -0.2068 & $0.0171 * * *$ & -0.2067 & $0.0173 * * *$ & -0.2050 & $0.0171 * * *$ & -0.2113 & $0.0165 * * *$ & -0.2105 & $0.0165 * * *$ & -0.2094 & $0.0167 * * *$ & -0.2092 & $0.0165 * * *$ & -0.2150 & $0.0164 * * *$ \\
\hline POOL & 0.3943 & $0.1100 * * *$ & 0.4020 & $0.1098 * * *$ & 0.4272 & $0.1150 * * *$ & 0.3968 & $0.1102 * * *$ & 0.4012 & $0.1103 * * *$ & & & & & 0.3437 & $0.1105 * * *$ \\
\hline SMALLPOOL & , & , & , & , & , & , & , & , & , & , & 0.3170 & $0.1732 *$ & & & , & \\
\hline LARGEPOOL & , & , & & & , & & , & , & & , & 0.4331 & $0.1201 * * *$ & & & , & \\
\hline POOL WITHOUT DISTRESS & , & 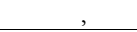 & , & , & , & , & , & , & , & , & , & & 0.3326 & $0.1269 * * *$ & & \\
\hline POOL IN DISTRESS & & & & & & & & & & & & & 0.5120 & $0.1517 * * *$ & & \\
\hline NUMBEROFBANKS & 0.0159 & 0.0138 & 0.0178 & 0.0137 & 0.0068 & 0.0144 & 0.0171 & 0.0137 & 0.0175 & 0.0137 & 0.0156 & 0.0139 & 0.0179 & 0.0137 & 0.0175 & 0.0136 \\
\hline HOUSEBANK & 0.1030 & 0.1927 & & & , & , & , & & , & , & , & & , & , & , & \\
\hline HOUSEBANK $x$ UNCOLLATERALIZED & -0.1922 & 0.2600 & & & & & & & & & & & & & & \\
\hline SINGLEBANK & & & 0.5982 & $0.3039 * *$ & 0.6196 & $0.3093 * *$ & 0.5788 & $0.3032 *$ & 0.5745 & $0.3035 *$ & 0.5739 & $0.3042 *$ & 0.5638 & $0.3026 *$ & 0.6335 & 0.3008 ** \\
\hline SINGLEBANK x UNCOLLATERALIZED & & & -1.6412 & $0.6698 * *$ & -1.5524 & $0.6897 * *$ & -1.6409 & $0.6735 * *$ & -1.6382 & $0.6749 * *$ & -1.6446 & $0.6781 * *$ & -1.6185 & $0.6715 * *$ & -1.7414 & $0.6688 * * *$ \\
\hline UNCOLLATERALIZED & -0.2535 & 0.1616 & -0.2557 & $0.1380 *$ & -0.3003 & $0.1422 * *$ & -0.2401 & $0.1372 *$ & -0.2480 & $0.1372 *$ & -0.2459 & $0.1375 *$ & -0.2625 & $0.1373 *$ & -0.2115 & 0.1362 \\
\hline LOG(DURATION) & 0.0402 & 0.0732 & 0.0406 & 0.0727 & & & & & & & & & & & , & \\
\hline LIABILITY & -0.0978 & 0.1649 & -0.1096 & 0.1648 & & & & & & & & & & & & \\
\hline LOG(SIZE) & -0.0991 & $0.0495 * *$ & -0.0927 & $0.0498 *$ & & & -0.0834 & $0.0505 *$ & -0.0920 & $0.0499 *$ & -0.0932 & $0.0501 *$ & -0.0893 & $0.0497 *$ & -0.0760 & 0.0496 \\
\hline LOG(SIZEA) & -0.1771 & $0.0748 * *$ & -0.1885 & 0.0741 ** & & & -0.1975 & $0.0754 * * *$ & -0.1788 & 0.0735 ** & -0.1791 & $0.0734 * *$ & -0.1795 & $0.0734 * *$ & -0.1891 & $0.0727 * * *$ \\
\hline EXPOSURE & & & & & -0.0085 & 0.0073 & & & , & , & & , & , & , & , & , \\
\hline BANKDEBT & & & & & 0.0007 & 0.0021 & & & & & & & & & & \\
\hline ROI & & & & & & & -0.2284 & 0.2150 & & & & & & & & \\
\hline BANK2 & 0.7194 & $0.2070 * * *$ & 0.7086 & $0.2030 * * *$ & 0.7856 & $0.2069 * * *$ & 0.6924 & $0.1999 * * *$ & 0.6980 & $0.1994 * * *$ & 0.7004 & $0.1978 * * *$ & 0.7065 & $0.2001 * * *$ & 0.7302 & $0.1971 * * *$ \\
\hline BANK3 & -0.3802 & $0.2216 *$ & -0.3942 & $0.2188 *$ & -0.5317 & $0.2099 * *$ & -0.4499 & 0.2019 ** & -0.4532 & $0.2016 * *$ & -0.4501 & $0.2003 * *$ & -0.4405 & $0.2023 * *$ & -0.4226 & 0.1992 ** \\
\hline BANK4 & -0.0198 & 0.2013 & -0.0070 & 0.1978 & 0.0277 & 0.2011 & -0.0241 & 0.1947 & -0.0275 & 0.1943 & -0.0256 & 0.1929 & -0.0249 & 0.1948 & 0.0035 & 0.1921 \\
\hline BANK5 & 0.0432 & 0.2223 & 0.0427 & 0.2196 & -0.0272 & 0.2160 & 0.0174 & 0.2104 & 0.0158 & 0.2099 & 0.0138 & 0.2082 & 0.0250 & 0.2107 & 0.0220 & 0.2073 \\
\hline SAMPLE P & & & & & & & & & & & & & & & 0.459404 & $0.140322 * * *$ \\
\hline \begin{tabular}{|l|} 
ONE \\
\end{tabular} & 5.3880 & $0.4212 * * *$ & 5.3710 & $0.4006 * * *$ & 4.5700 & $0.2277 * * *$ & 5.5432 & $0.3193 * * *$ & 5.4664 & $0.3114 * * *$ & 5.4718 & $0.3111 * * *$ & 5.4604 & $0.3113 * * *$ & 5.3192 & $0.3109 * * *$ \\
\hline $\mathrm{N}$ & 644.00 & & 644.00 & & 624.00 & & 644.00 & & 644.00 & & 644.00 & & 644.00 & & 644.00 & \\
\hline R-squared & 0.3489 & & 0.3574 & & 0.3346 & & 0.3569 & & 0.3568 & & 0.3629 & & 0.3576 & & 0.3730 & \\
\hline LM-Test & 308.69 & $* * *$ & 303.52 & $* * *$ & 292.12 & $* * *$ & 303.94 & **** & 304.86 & **** & 295.57 & $* * *$ & 305.07 & $* * *$ & 302.03 & *** \\
\hline
\end{tabular}




\section{1st stage}

The table reports regression results on the bank's pool formation. We estimate a standard probit model with dummy variables for each observation year controlling for the panel structure of the data. The dependent variable is the pool dummy equal to one when a pool is observed. All explanatory variables are defined in Table 8 . The level of significnce vare indicated as follows: $1 \%(* * *), 5 \%(* *)$, $10 \%(*)$. N gives the number of observations.

\begin{tabular}{|l|rl|}
\hline & (i) & \\
& Coeff. & Std.Err. \\
\hline BANK1 & -3.4021 & $1.8818^{*}$ \\
\hline BANK2 & -2.7860 & 1.8332 \\
\hline BANK3 & -1.9968 & 1.8700 \\
\hline BANK4 & -3.0683 & $1.8527 *$ \\
\hline BANK5 & -2.9814 & 1.8611 \\
\hline IFO & 0.0152 & 0.0208 \\
\hline RATING3 & 0.1691 & 0.2254 \\
\hline RATING4 & 0.6711 & $0.2222 * * *$ \\
\hline RATING5-6 & 1.3347 & $0.2297 * * *$ \\
\hline NUMBEROFBANKS & 0.0170 & 0.0157 \\
\hline HOUSEBANK & 0.2370 & $0.1432 *$ \\
\hline UNCOLLATERALIZED & -0.6369 & $0.2182 * * *$ \\
\hline LIABILITY & -0.2900 & 0.1979 \\
\hline LOG(DURATION) & -0.1296 & 0.0838 \\
\hline LOG(SIZE) & 0.3572 & $0.1318 * * *$ \\
\hline LOG(SIZEA) & -0.3220 & $0.1428 * *$ \\
\hline BANKDEBT & 0.0084 & $0.0028 * *$ \\
\hline YEAR1994 & -0.0101 & 0.3318 \\
\hline YEAR1995 & 0.2046 & 0.2619 \\
\hline YEAR1996 & 0.3421 & 0.2242 \\
\hline & & \\
\hline & & \\
\hline N & & \\
\hline Chi-squared & 624.00 & \\
\hline & 158.39 & \\
\hline
\end{tabular}

2nd stage

The table reports regression results of a two-stage estimation on the bank's pricing decision on short-term credit lines (LC). We test a one-way error component random effects model using the estimated pool variable form a probit regression in the 1st stage as instrumental variable. The instrument is also employed within the pool interaction terms. The dependent variable is the spread measured as the difference between the bank's nominal interest rate charged on short-term credit lines and the 3-months Frankfurt Interbank Offered Rate (FIBOR). All explanatory variables are defined in Table 8 . The levels of significance are indicated as follows: $1 \%$ $(* *), 5 \%(* *), 10 \%(*)$. N gives the number of observations. The LM-Test statistic refers to the Breusch-Pagan L arange multiplier test testing for random effects. If the null hypothesis of zero group variance cannot be rejected the pooled OLS regression is appropriate. If the LM-Test statistics is sufficiently large, the null hypothesis is rejected in favor of the random effects model.

\begin{tabular}{|c|c|c|c|c|c|c|c|c|}
\hline & (v.2) & & (vi.2) & & (vii.2) & & (v.2.P) & \\
\hline & Coeff. & Std.Err. & Coeff. & Std.Err. & Coeff. & Std.Err. & Coeff. & Std.Err. \\
\hline RATING3 & 0.2860 & 0.1089 *** & 0.2892 & 0.1087 *** & 0.2858 & 0.1086 *** & 0.2607 & $0.1077^{* *}$ \\
\hline RATING4 & 0.3610 & 0.1163 *** & 0.3614 & $0.1160 * * *$ & 0.3683 & 0.1172 *** & 0.2954 & $0.1162 * *$ \\
\hline RATING5-6 & 0.3370 & $0.1309 * *$ & 0.3360 & $0.1306 * *$ & 0.3075 & $0.1368 * *$ & 0.1795 & 0.1361 \\
\hline FIBOR3M & -0.2167 & $0.0170 * * *$ & -0.2164 & $0.0169 * * *$ & -0.2160 & $0.0169 * * *$ & -0.2199 & $0.0168^{* * *}$ \\
\hline POOL IV & 0.3921 & $0.1284^{* * *}$ & & & & & 0.3862 & $0.1267 * * *$ \\
\hline SMALLPOOL IV & , & , & 0.1789 & 0.1893 & , & , & , & , \\
\hline LARGEPOOL IV & , & , & 0.5026 & $0.1471 * * *$ & & & , & , \\
\hline POOL WITHOUT DISTRESS IV & & , & & & 0.3098 & $0.1827 *$ & & \\
\hline POOL IN DISTRESS IV & & & & & 0.4474 & $0.1549 * * *$ & & \\
\hline NUMBEROFBANKS & 0.0234 & 0.0145 & 0.0214 & 0.0145 & 0.0235 & 0.0145 & 0.0224 & 0.0143 \\
\hline SINGLEBANK & 0.5429 & $0.3091 *$ & 0.5496 & $0.3082 *$ & 0.5373 & $0.3084 *$ & 0.6234 & $0.3053 * *$ \\
\hline SINGLEBANK x UNCOLLATERALIZED & -1.6088 & $0.6858 * *$ & -1.6227 & $0.6842 * *$ & -1.6001 & $0.6832 * *$ & -1.7458 & $0.6780 * *$ \\
\hline UNCOLLATERALIZED & -0.2776 & $0.1412 * *$ & -0.2555 & $0.1415 *$ & -0.2820 & $0.1409 * *$ & -0.2196 & 0.1400 \\
\hline LOG(SIZE) & -0.0919 & $0.0510 *$ & -0.0932 & 0.0508 & -0.0893 & $0.0509 *$ & -0.0750 & 0.0505 \\
\hline LOG(SIZEA) & -0.1599 & $0.0767 * *$ & -0.1686 & $0.0766 * *$ & -0.1587 & $0.0767 * *$ & -0.1764 & $0.0755 * *$ \\
\hline BANK2 & 0.6634 & $0.2106 * * *$ & 0.6563 & $0.2099 * * *$ & 0.6595 & $0.2112 * * *$ & 0.7247 & $0.2070 * * *$ \\
\hline BANK3 & -0.4973 & $0.2158 * *$ & -0.5055 & $0.2151 * *$ & -0.4915 & $0.2164 * *$ & -0.4691 & $0.2118 * *$ \\
\hline BANK4 & -0.0119 & 0.2020 & -0.0142 & 0.2013 & -0.0140 & 0.2026 & 0.0249 & 0.1982 \\
\hline BANK5 & -0.0059 & 0.2183 & -0.0139 & 0.2176 & -0.0099 & 0.2190 & 0.0044 & 0.2140 \\
\hline SAMPLE P & & & & & & & 0.5419 & $0.1442 * * *$ \\
\hline ONE & 5.4807 & $0.3268 * * *$ & 5.5146 & $0.3265 * * *$ & 5.4699 & $0.3275 * * *$ & 5.2966 & $0.3248 * * *$ \\
\hline $\mathbf{N}$ & 624.00 & & 624.00 & & 624.00 & & 624.00 & \\
\hline R-squared & 0.3283 & & 0.3338 & & 0.3286 & & 0.3528 & \\
\hline LM-Test & 308.04 & $* * *$ & 304.12 & $* * *$ & 307.01 & $* * *$ & 303.45 & *** \\
\hline
\end{tabular}




\section{CFS Working Paper Series:}

\begin{tabular}{|c|c|c|}
\hline No. & Author(s) & Title \\
\hline $2010 / 06$ & $\begin{array}{l}\text { Roman Kräussl } \\
\text { André Lucas } \\
\text { David R. Rijsbergen, } \\
\text { Pieter Jelle van der Sluis } \\
\text { Evert B. Vrugt }\end{array}$ & $\begin{array}{l}\text { Washington Meets Wall Street: A Closer } \\
\text { Examination of the Presidential Cycle Puzzle }\end{array}$ \\
\hline $2010 / 05$ & $\begin{array}{l}\text { Sander J.J. Konijn } \\
\text { Roman Kräussl } \\
\text { Andre Lucas }\end{array}$ & Blockholder Dispersion and Firm Value \\
\hline $2010 / 04$ & $\begin{array}{l}\text { Narasimhan Jegadeesh } \\
\text { Roman Kräussl } \\
\text { Joshua Pollet }\end{array}$ & $\begin{array}{l}\text { Risk and Expected Returns of Private Equity } \\
\text { Investments: Evidence Based on Market } \\
\text { Prices }\end{array}$ \\
\hline $2010 / 03$ & $\begin{array}{l}\text { Roman Kraeussl } \\
\text { Christian Wiehenkamp }\end{array}$ & A Call on Art Investments \\
\hline $2010 / 02$ & $\begin{array}{l}\text { Roman Kraeussl } \\
\text { Stefan Krause }\end{array}$ & $\begin{array}{l}\text { Are particular industries more likely to } \\
\text { succeed? A comparative analysis of VC } \\
\text { investment in the U.S. and Europe }\end{array}$ \\
\hline $2010 / 01$ & $\begin{array}{l}\text { Nikolaus Hautsch } \\
\text { Dieter Hess } \\
\text { David Veredas }\end{array}$ & $\begin{array}{l}\text { The Impact of Macroeconomic News on Quote } \\
\text { Adjustments, Noise, and Informational } \\
\text { Volatility }\end{array}$ \\
\hline $2009 / 32$ & $\begin{array}{l}\text { Guenter W. Beck } \\
\text { Kirstin Hubrich } \\
\text { Massimiliano Marcellino }\end{array}$ & $\begin{array}{l}\text { On the importance of sectoral shocks for } \\
\text { price-setting }\end{array}$ \\
\hline $2009 / 31$ & $\begin{array}{l}\text { Axel Groß-Klußmann } \\
\text { Nikolaus Hautsch }\end{array}$ & $\begin{array}{l}\text { Quantifying High-Frequency Market Reactions } \\
\text { to Real-Time News Sentiment } \\
\text { Announcements }\end{array}$ \\
\hline $2009 / 30$ & Volker Wieland & $\begin{array}{l}\text { Quantitative Easing: } \\
\text { A Rationale and Some Evidence from Japan }\end{array}$ \\
\hline
\end{tabular}

Copies of working papers can be downloaded at http://www.ifk-cfs.de 